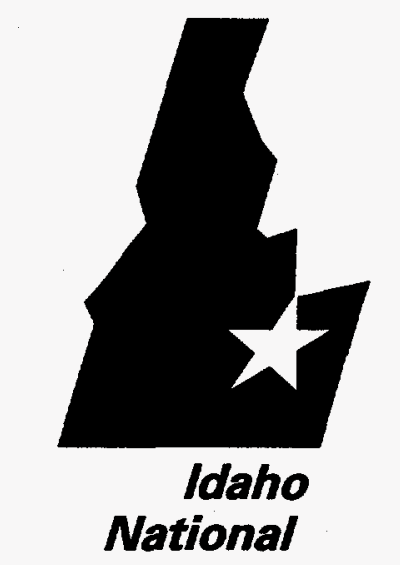

Engineering

Laboratory
INEL-96/0113

March 1996

\section{Alternate Fluid To Improve Energy Efficiency of Supercritical Water Oxidation Process}

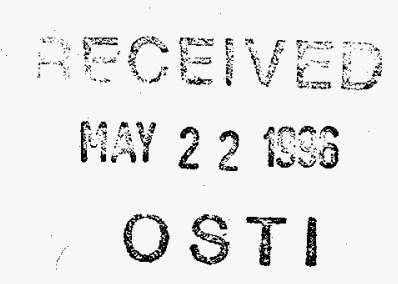

Chang H. Oh

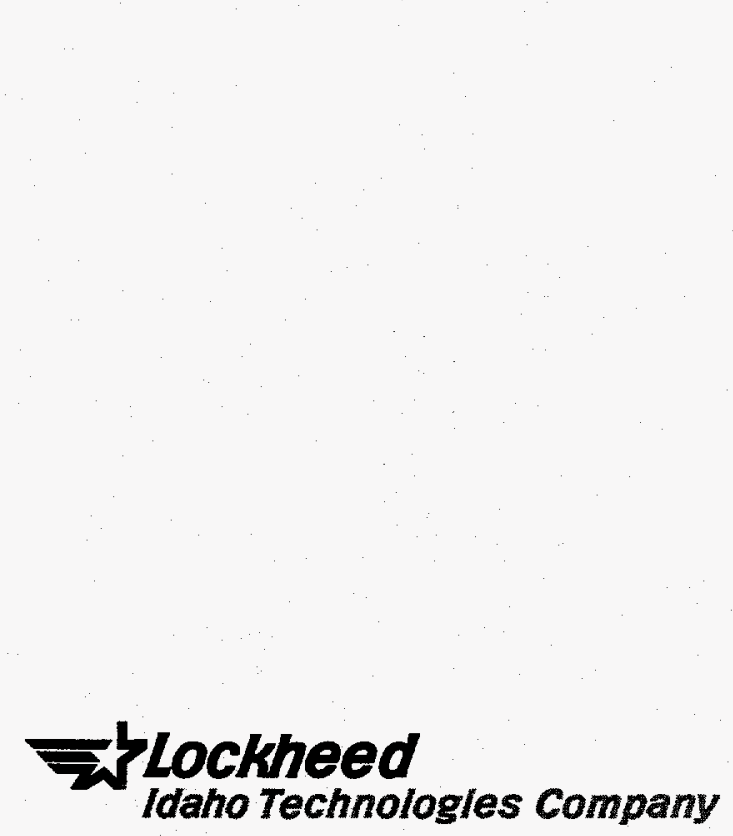

DISTRIBUTION OF THS DOOUMENT IS UNLMTED

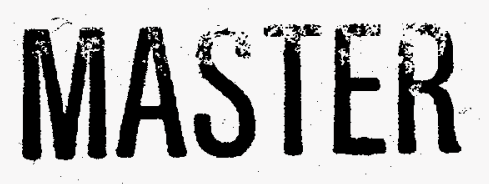




\section{DISCLAMMER}

Portions of this document may be illegible in electronic image products. Images are produced from the best available original document. 


\title{
ALTERNATE FLUID TO IMPROVE ENERGY EFFICIENCY OF SUPERCRITICAL WATER OXIDATION PROCESS
}

Chang H. Oh

Published March 1996

Idaho National Engineering Laboratory Lockheed Idaho Technologies Company Idaho Falls, Idaho 83415

\author{
Prepared for the \\ U.S. Department of Energy \\ Assistant Secretary for Environmental Management \\ Under DOE Idaho Operations Office \\ Contract No. DE-AC07-94ID13223
}





\title{
ABSTRACT
}

This report discusses the replacement of water by carbon dioxide in both the quench stream and the supercritical water oxidation (SCWO) reactor feed in order to reduce the energy utilization in the process. FLUENT was used to generate the input requirements and ASPEN PLUS was used to model the SCWO process. Simulations were made for normal MODAR operating conditions (baseline case) and two other cases replacing water by carbon dioxide. The basis for and assumptions used in the simulation are given.

Economic evaluations were made and costs were compared with the baseline case and a case with $60 \%$ replacement of water by carbon dioxide. The equipment cost is almost the same. However, the case with replacement of water by carbon dioxide reduces the energy requirement in the end process by a factor of three, which is a significant energy savings in the operation.

Also, the injection of carbon dioxide into the SCWO reactor feed is expected to reduce corrosion and makes salt particles non-sticky. However, these advantages need to be confirmed by experiment.

\section{DISCLAIMER}

\begin{abstract}
This report was prepared as an account of work sponsored by an agency of the United States Government. Neither the United States Government nor any agency thereof, nor any of their employees, makes any warranty, express or implied, or assumes any legal liability or responsibility for the accuracy, completeness, or usefulness of any information, apparatus, product, or process disclosed, or represents that its use would not infringe privately owned rights. Reference herein to any specific commercial product, process, or service by trade name, trademark, manufacturer, or otherwise does not necessarily constitute or imply its endorsement, recommendation, or favoring by the United States Government or any agency thereof. The views and opinions of authors expressed herein do not necessarily state or reflect those of the United States Government or any agency thereof.
\end{abstract}




\section{CONTENTS}

ABSTRACT $\ldots \ldots \ldots \ldots \ldots \ldots \ldots \ldots \ldots \ldots \ldots \ldots \ldots \ldots \ldots \ldots \ldots \ldots \ldots \ldots \ldots \ldots$

1. INTRODUCTION $\ldots \ldots \ldots \ldots \ldots \ldots \ldots \ldots \ldots \ldots \ldots \ldots \ldots \ldots \ldots \ldots$

2. THE CURRENT SCWO PROCESS $\ldots \ldots \ldots \ldots \ldots \ldots \ldots \ldots \ldots \ldots \ldots \ldots \ldots \ldots$

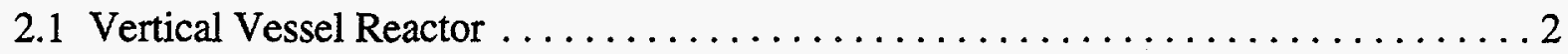

2.2 Transpiring Platelet Reactor. . . . . . . . . . . . . . . . . .

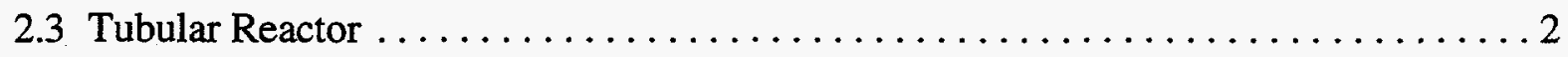

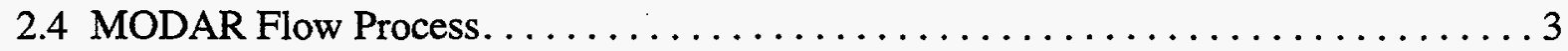

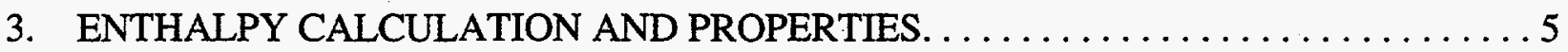

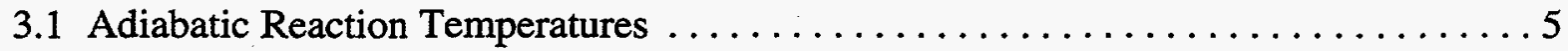

3.2 Enthalpies of Formation $\ldots \ldots \ldots \ldots \ldots \ldots \ldots \ldots \ldots \ldots \ldots \ldots \ldots \ldots \ldots \ldots \ldots \ldots \ldots \ldots \ldots$

3.3 Thermodynamic and Transport Properties $\ldots \ldots \ldots \ldots \ldots \ldots \ldots \ldots \ldots \ldots$

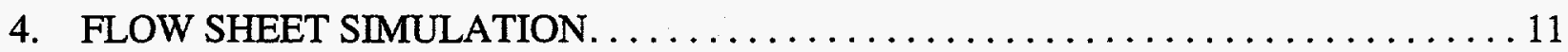

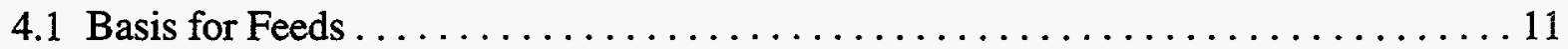

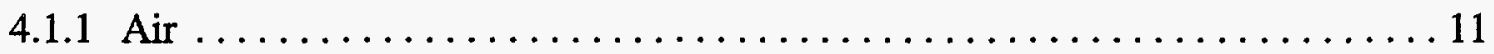

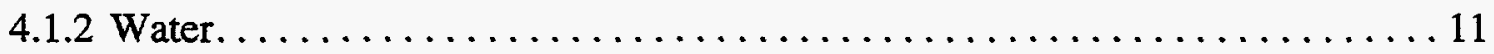

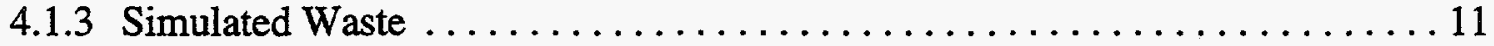

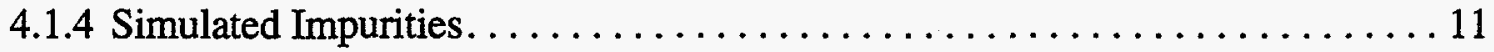

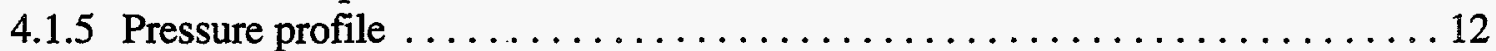

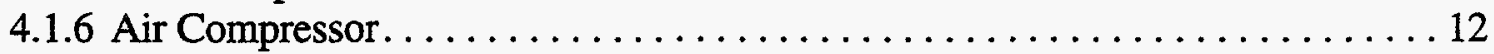

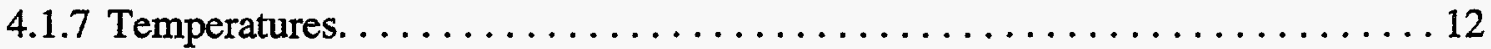

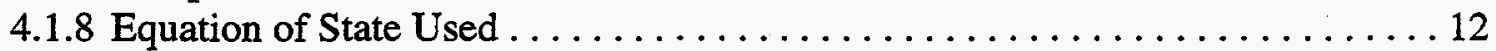

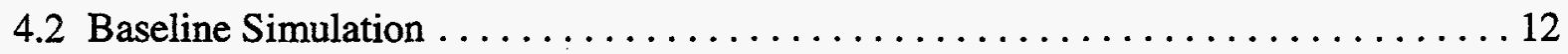

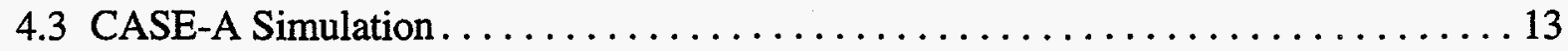

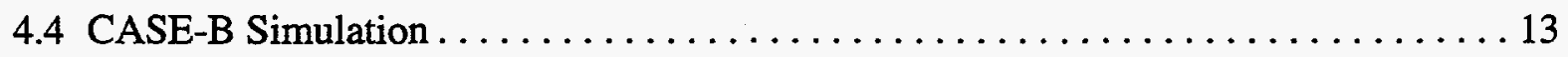

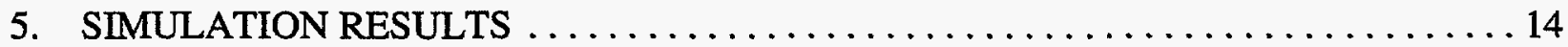

6. ECONOMIC EVALUATION. ......................... 28 
7. CONCLUSIONS

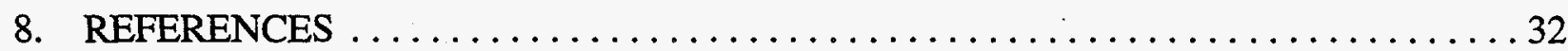

\section{FIGURES}

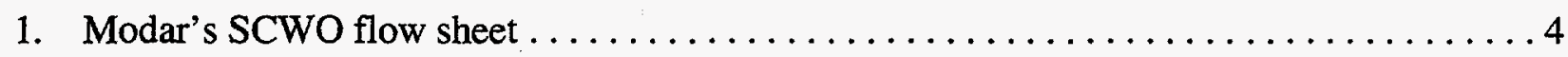

2. Specific heats of SCWO fluids...........................

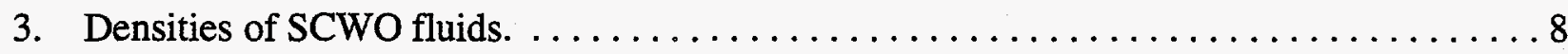

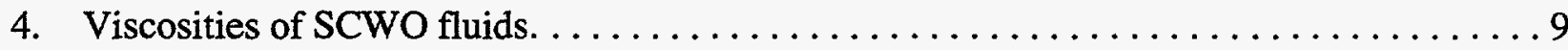

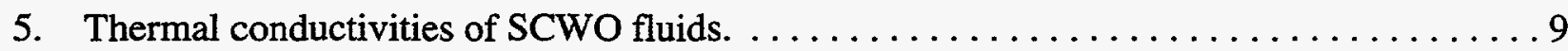

6. Comparison of water specific heat calculated from NBS steam tables with the approximation used in FLUENT model at 3500 psia and near the critical

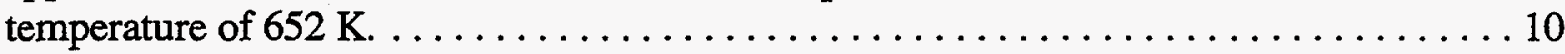

7. SCWO Flow Sheet for Baseline Case. .......................... 14

8. SCWO Flow Sheet for Case-A.............................. 18

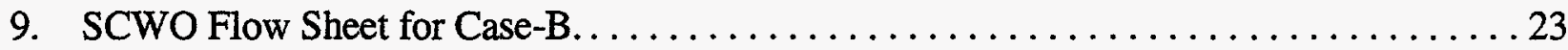




\section{ALTERNATE FLUID TO IMPROVE ENERGY EFFICIENCY OF SUPERCRITICAL WATER OXIDATION PROCESS}

\section{INTRODUCTION}

Because supercritical water has unique characteristic which makes organics miscible in it, water at supercritical conditions $\left(\mathrm{Tc}=374^{\circ} \mathrm{C}, \mathrm{Pc}=218 \mathrm{~atm}\right)$ is used as a solvent for mixing, a heat transfer media for preheating, a heat sink to control the fluid temperature, and a coolant to quench the reactor effluents in the supercritical water oxidation process. The extensive use of water to quench the effluent stream process results in very high energy requirements when separating this stream at the end process unit because water has a high heat of vaporization. We propose to replace as much of the water stream as possible by an alternate fluid which has heat transfer characteristics similar to those of water but which can be more economically separated from the hazardous or mixed wastes streams.

The MODAR process uses quench water flowrates that are 1.6 times the reactor effluent flowrate to quench the effluent to less than $300^{\circ} \mathrm{C}$ before the first separator. This massive amount of water used in the quench stream goes into the end process unit where the water must be processed to separate wastes from the water. Preliminary ASPEN PLUS calculations indicate that carbon dioxide, one of the alternate fluid candidates, can be used to replace most of the quench water stream while adequately cooling the reactor effiuents. It is recycled from the first separator, and is easily separately as a gas from the ppm level impurities in the end process.

This replacement results in significant water reduction in the end process, which reduces the energy duty by a factor of 3 in the end process unit and makes the supercritical water oxidation (SCWO) technology more economically viable. In addition, the replacement of water in the reactor feed by carbon dioxide would alleviate much of the sticky salt deposit problem because the salts remain in a solid form in the carbon dioxide environment due to the lower solubility of salt in carbon dioxide. In the water environment some salts remain sticky. Also, the higher viscosity of carbon dioxide at the supercritical conditions would minimize the corrosion problem because of the lower mass transfer rate of heteroatoms (e.g.,chlorine, sulphur, etc.) to the wall. 


\section{THE CURRENT SCWO PROCESS}

There are three SCWO reactor configurations: tubular reactor, vertical vessel reactor, and transpiring platelet reactor, a porous wall reactor concept. The flow mixing is strongly coupled with the chemical kinetics and affects the destruction efficiency. ${ }^{1,2}$ Therefore the flow mixing is very important and is dependant on the reactor geometry and the mixing device of the waste stream and air stream. The brief generic descriptions of the reactor concepts are summarized below.

\subsection{Vertical Vessel Reactor}

The vertical reactor concept consists of a co-axial nozzle for the feed stream, a brine pool in the lower conical section to separate salts, a cylindrical space for the oxidation and an outlet pipe in the upper section. The unique design characteristics of this configuration provide a brine pool to separate salts at the bottom of the reactor and the reaction effluents are removed through the pipe located in the upper section. Due to the flow exit at the upper section, the flow generates a recirculation pattern downstream of the nozzle. The flow entrainment caused by this recirculation provides a backmixing which preheats the incoming waste stream. Also, the nozzle design is very important for the reactant mixing and salt precipitation behavior.

\subsection{Transpiring Platelet Reactor}

This configuration is very similar to a straight tubular reactor, but it has a porous liner along the tube wall. Supercritical water and/or oxidants are injected radially into the axial waste flow to protect the wall from thermal stress, corrosion, and salt deposition on the wall surface. The reactor configuration consists of three sections: a preheating section, a reaction section, and a cooldown section. In the preheating section, hot water is injected through the porous wall to prèheat the waste stream and to provide a boundary layer to protect the wall from corrosion expected at $400^{\circ} \mathrm{C}$, which is the mixing temperature in the preheating section. In the reaction section, hot air and supercritical water (SCW) are flowed through the porous wall while cold water is injected through the cooldown section porous wall to cool down the reaction effluent. In these regions, the amount of water injected through the porous wall must be processed in the end unit, which is an evaporator or ion exchange column.

\subsection{Tubular Reactor}

The simplest design of a SCWO reactor is a thin tubular pipe whose heated initial length serves as a preacher to bring the high pressure feeds to temperatures above the critical point of water. The oxidation then begins in the section in the mid portion of the reactor, in which the reactants are heated by the exothermic heat release to temperatures above the critical temperature and the reaction rate increases. Because the flow is plug flow, there is no radial mixing to promote flow mixing. As a result, this configuration requires a lengthy pipe. Since the reactor is long with a small diameter, salt precipitation on the reactor wall is a plaguing problem, because it can cause plug up the reactor. 


\subsection{MODAR Flow Process}

Figure 1 shows a schematic of a typical MODAR pilot scale flow sheet. Air and water are fed through a heat exchanger into the reactor via the outer nozzle and waste and water via the inner nozzle. If the reaction generates acids, a neutralizing chemical such as $\mathrm{NaCl}$ is added to the waste stream stoichiometrically. The oxidation reaction occurs downstream of the nozzle, generating reaction products such as carbon dioxide and water. Heteroatoms are converted into inorganic compounds, usually acids, salts or oxides. Sulfur, if present in the feed stream, is converted into sulfate, phosphorus to phosphate, and halogens to haloacids. The reaction products, carbon dioxide and water, exit at the upper portion of the reactor and are filtered before they go to a heat exchanger to cool down. After they flow through another cooler, they enter the first separator, a medium pressure separator (1500 psia), where gases are removed at the top and liquids are fed into the second separator, a low pressure separator (100 psia), where the gas and liquid are removed at the top and bottom, respectively. If the liquid is still contaminated, it is recycled back to the reactor. If this occurs, it will reduce the waste treatment capacity. In chemical plants, the contaminated stream is treated in an ion-exchange column and/or evaporator. Precipitated salts are dissolved in the brine pool and removed at the bottom of the reactor. Then, the brine is separated at a third separator, a medium pressure separator (1450 psia).

Regardless of reactor types used in the SCWO process, the flow process is very similar to Figure 1 and requires a quenching system. In the vertical vessel reactor and tubular reactor, the quench stream is mixed with the reactor effluent stream, while the transpiring platelet reactor uses radial mixing in the reactor through the porous wall. 


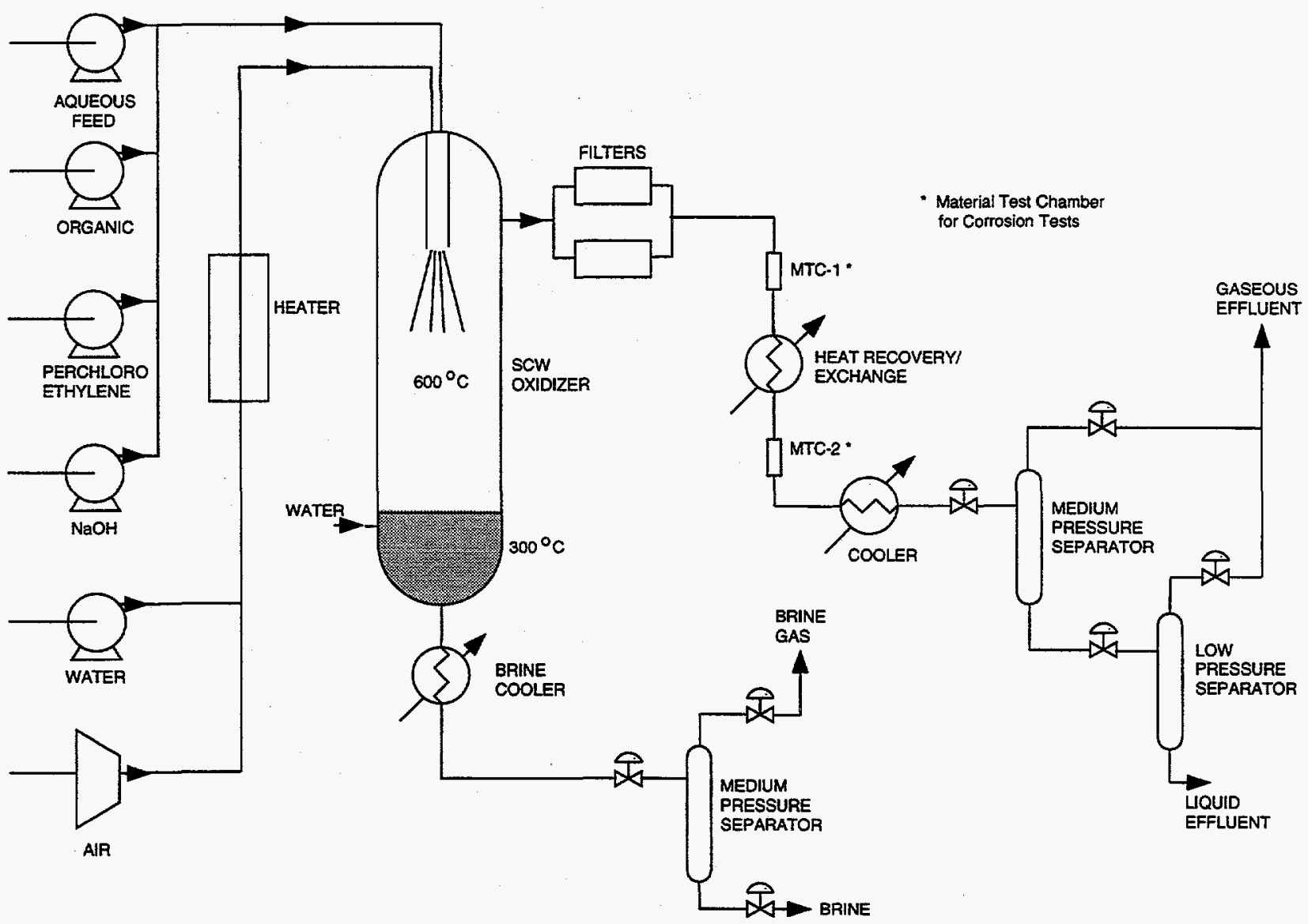

Figure 1. Modar's SCWO flow sheet 


\section{ENTHALPY CALCULATION AND PROPERTIES}

\subsection{Adiabatic Reaction Temperatures}

We developed a method to calculate the adiabatic reaction temperature so it could be used to estimate the reactor temperature as a function of flows and temperatures of the input streams; this was determined to be very helpful in establishing sensitivities of reactor temperature to flow parameters and fluid properties. $3,4,5,6$

The adiabatic reaction temperature is defined as the temperature that would be reached if the fuel and oxidant streams mixed and reacted adiabatically. If the heat losses from the reactor are low, as they are in this pilot scale reactor, the steady state (mixed) outlet temperatures predicted by FLUENT $^{7}$ will converge to a value very near the theoretical adiabatic reaction temperature.

FLUENT solves the energy equation in terms of conservation of the static enthalpy, $h$, defined as:

$$
h=\sum_{i} m_{i} h_{i}
$$

where

$$
h_{i}=\int_{T_{\text {ref }}}^{T} c_{p, i} d T
$$

where $m_{i}$ is the mass fraction, $T_{r e f}$ is a reference temperature $(300 \mathrm{~K}$ in these calculations) and $c_{p, i}$ is the specific heat at constant pressure of species $i$. This sensible enthalpy does not include the enthalpy of formation of each species. For chemically reacting flows FLUENT calculates the instantaneous enthalpy, $h^{*}$, as:

$$
\begin{aligned}
h^{*} & =\sum_{i} m_{i}\left[\int_{T_{r e f}}^{T} c_{p, i} d T+\frac{h_{i}^{o}}{M_{i}}+\int_{T_{r e f_{i}}}^{T_{r e f}} c_{p, i} d T\right] \\
& =\sum_{i} m_{i}\left[\int_{T_{r e f_{i}}}^{T} c_{p, i} d T+\frac{h_{i}^{o}}{M_{i}}\right]
\end{aligned}
$$

where $h_{\mathrm{i}}^{\circ}$ is the enthalpy of formation of species $i$ obtained at reference temperature $T_{\text {ref }}$ (298.15 $\mathrm{K}$ in these calculations, see enthalpy of formation in 3.2.1), and $M_{i}$ is the molecular weight of species $i$. FLUENT calculates and lists the values of $h^{*}$ for each cell in the computational domain using the temperatures, compositions, and properties available to it. 
We calculate the adiabatic reaction temperature by mixing the instantaneous enthalpies of the core flow and the annular flow (fuel and oxidant, respectively) to obtain a mass averaged instantaneous enthalpy which, in the FLUENT representation, includes the heat of reaction, i. e.,

$$
h_{\text {mixed }}^{*}=\frac{h_{\text {core }}^{*} \dot{m}_{\text {core }}+h_{\text {annulus }}^{*} \dot{m}_{\text {annulus }}}{\dot{m}_{\text {core }}+\dot{m}_{\text {annulus }}}
$$

where $\dot{m}$ is the mass flow rate of the core and annulus.

FLUENT calculates the enthalpy at the core and annulus inlets based upon the model input conditions. Then, using complete oxidation compositions, a temperature is found by trial and error which results in the same mixed enthalpy as calculated above. This is the adiabatic reaction temperature. Using FLUENT to perform the enthalpy calculations we were able to ensure that the properties used and the calculation method matched those in the actual FLUENT runs. Inherent in this calculational method is the assumption of negligible heat transfer from the reaction zone. This is a good assumption because the reactor is well insulated in the upper regions of the reactor bounding the reaction zone. Also, since the lower region has very low flows, there is poor heat transfer between the hot reaction zone and the cold brine region.

Table 1 shows the results of our calculations of hot stream inlet temperatures as a function of both the core (inner nozzle) and annulus (outer nozzle) stream flowrates in order to achieve the adiabatic fluid temperature at $600^{\circ} \mathrm{C}$. This calculation was iterative assuming the inlet stream temperature and achieving the adiabatic temperature at $600^{\circ} \mathrm{C}$. An IPA flowrate of $165 \mathrm{lb} / \mathrm{hr}$ was used for all the calculations.

Table 1. Adiabatic reaction temperature

\begin{tabular}{|c||c|c|}
\hline Case & $\begin{array}{c}\text { Feed rate to nozzle } \\
(\mathrm{lb} / \mathrm{hr})\end{array}$ & $\begin{array}{c}\text { Hot stream inlet } \\
\text { temperature }(\mathrm{F})\end{array}$ \\
\hline \hline Baseline & $3155 \mathrm{H}_{2} \mathrm{O}$ & 1112 \\
\hline Case-A & $\begin{array}{c}2585 \mathrm{H}_{2} \mathrm{O} \text { and } \\
571 \mathrm{CO}_{2}(40 \% \text { replacement })\end{array}$ & 930 \\
\hline Case-B & $\begin{array}{c}2869 \mathrm{H}_{2} \mathrm{O} \text { and } \\
286 \mathrm{CO}_{2}(20 \% \text { replacement })\end{array}$ & 1012 \\
\hline
\end{tabular}

\subsection{Enthalpies of Formation}

The formation enthalpies for all species entering into the chemical reactions, together with 
the reference temperatures at which these are defined, are required in the FLUENT model. The values used in these calculations were obtained from Reference 8 and are shown in Table 2.

Table 2. Enthalpies of formation for SCWO species.

\begin{tabular}{|c|c|c|}
\cline { 2 - 3 } & $\begin{array}{c}\text { Formation enthalpy } \\
(\mathrm{J} / \mathrm{kmol})\end{array}$ & $\begin{array}{c}\text { Reference } \\
\text { temperature } \\
(\mathrm{K})\end{array}$ \\
\hline \hline $\mathrm{C}_{3} \mathrm{H}_{8} \mathrm{O}$ & $-3.11 \mathrm{E} 08$ & 298.15 \\
\hline $\mathrm{H}_{2} \mathrm{O}$ & $-2.85 \mathrm{E} 08$ & 298.15 \\
\hline $\mathrm{CO}_{2}$ & $-3.94 \mathrm{E} 08$ & 298.15 \\
\hline $\mathrm{O}_{2}$ & 0 & 298.15 \\
\hline $\mathrm{N}_{2}$ & 0 & 298.15 \\
\hline
\end{tabular}

In the above table the formation enthalpies of IPA and water were taken to be those of the liquid state, while that of $\mathrm{CO}_{2}$ was taken to be a gas, representing their initial states.

\subsection{Thermodynamic and Transport Properties}

The critical point of water is at 3206 psia $(22.1 \mathrm{MPa})$ and $374^{\circ} \mathrm{C}$. A SCWO reactor is typically run at a pressure somewhat higher than the critical pressure; the reactor simulated in this report was operated at a constant pressure of 3500 psia $(23.8 \mathrm{MPa})$.

The five chemical species considered in this application include IPA, water, carbon dioxide, oxygen, and nitrogen. Properties needed for the calculations include the specie densities, specific heats, viscosities, and thermal conductivities. These properties were obtained from the Aspen code $^{9}$ as a function of temperature for the range of $300 \mathrm{~K}$ to $1500 \mathrm{~K}$ and a constant pressure of 3400 psia. The vessel reactor has a relatively low pressure drop so the approximation of constant pressure properties will not introduce a significant error into the calculations. Water properties were calculated using the NBS correlations in the Aspen code, while the properties of the other fluids were calculated with the SR-Polar option.

Figure 2 through Figure 5 show the specific heat, density, viscosity, and thermal conductivity of all the species used in this study and also those of ethanol (ethanol was used in the bench scale study in Reference 5 ). 


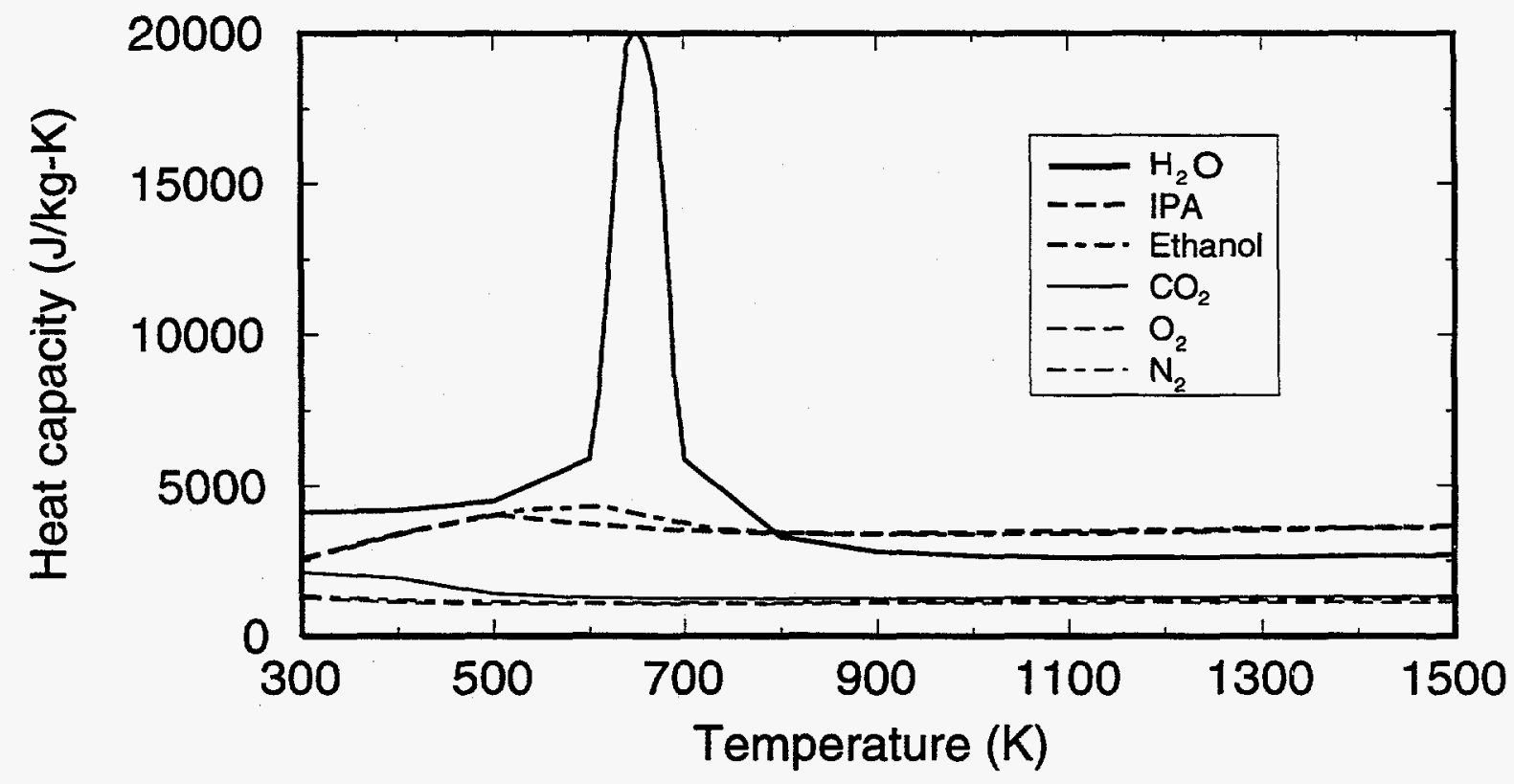

Figure 2. Specific heats of SCWO fluids.

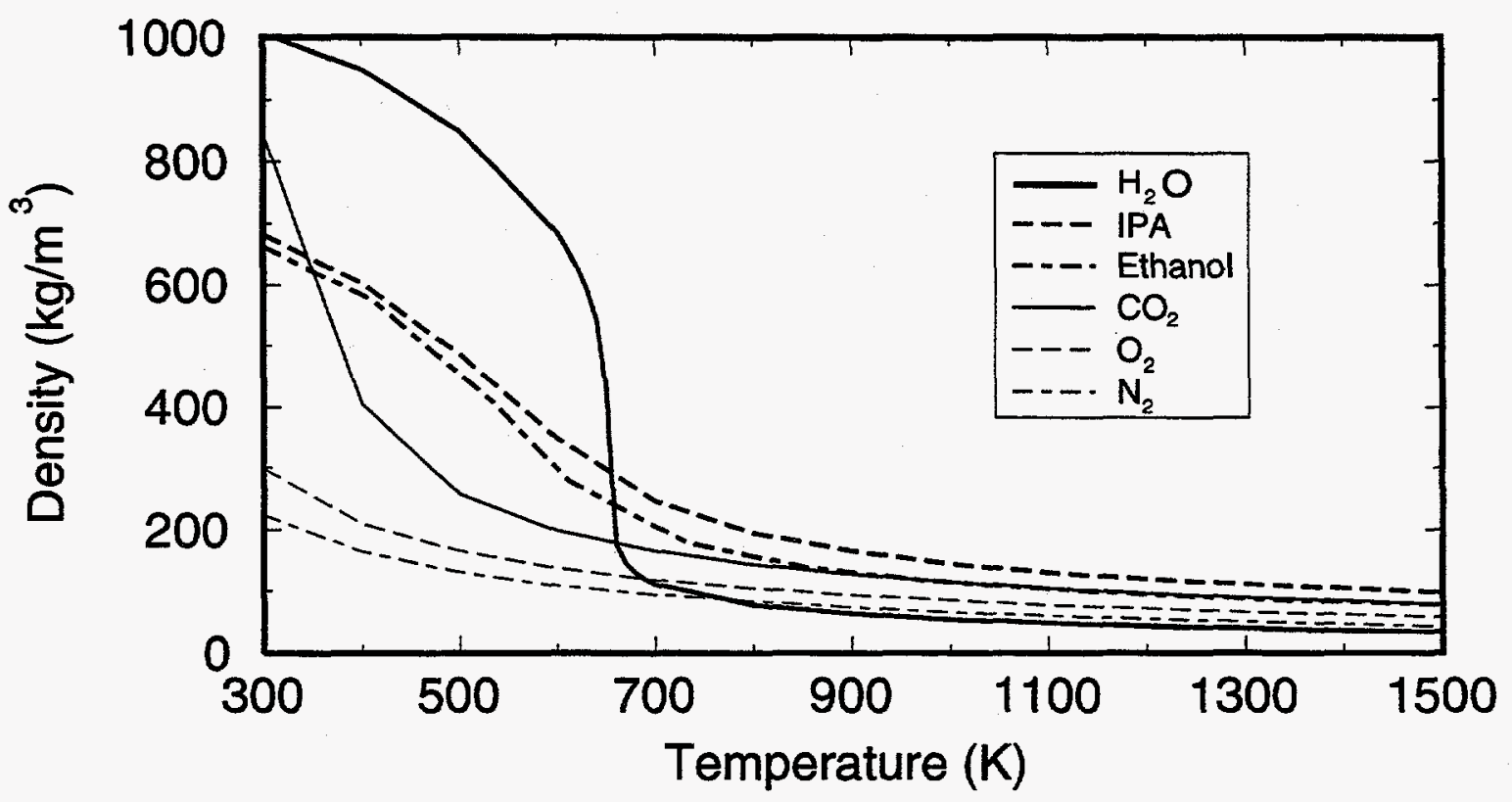

Figure 3. Densities of SCWO fluids. 


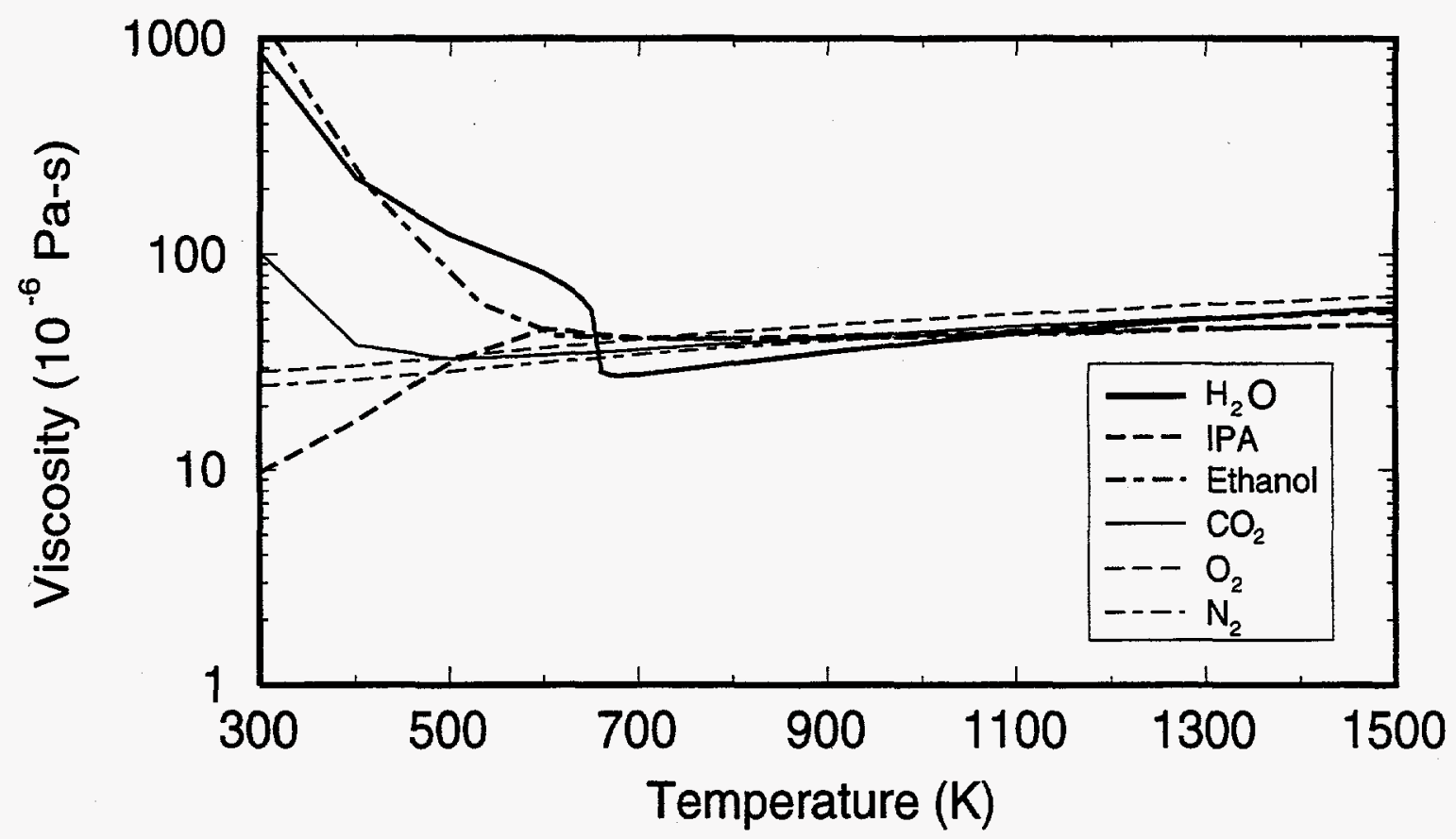

Figure 4. Viscosities of SCWO fluids.

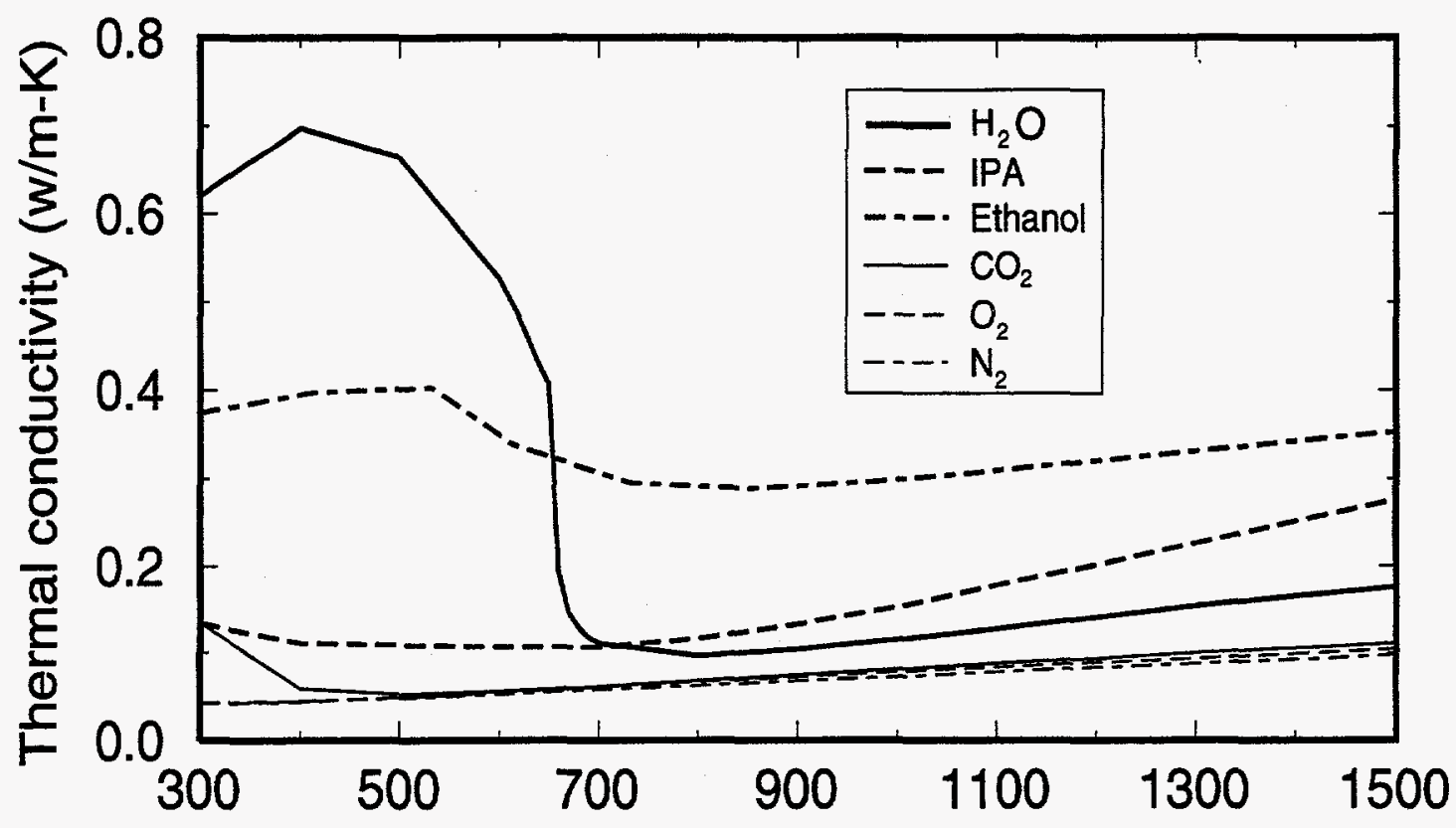

Figure 5. Thermal conductivities of SCWO fluids. 
FLUENT computes the mixture density from the individual specie densities as:

$$
\rho=\frac{1}{\sum_{i} \frac{m_{i}}{\rho_{i}}}
$$

where $m_{i}$ is the mass fraction and $\rho_{i}$ is the density of species $i$.

FLUENT computes the mixture heat capacity, viscosity, and thermal conductivity (shown for heat capacity) as:

$$
c_{p}=\sum_{i} m_{i} c_{p, i}
$$

where $c_{p, i}$ (or $\mu_{i}$ or $k_{i}$ ) are the specie properties.

Figure 6 shows a comparison between the approximations of specific heat of water used in this study and the values predicted using the ASPEN NBS steam tables in Reference 9 . Figure A.37 in Reference 10 shows that the NBS steam tables are very accurate in the vicinity of the critical point .

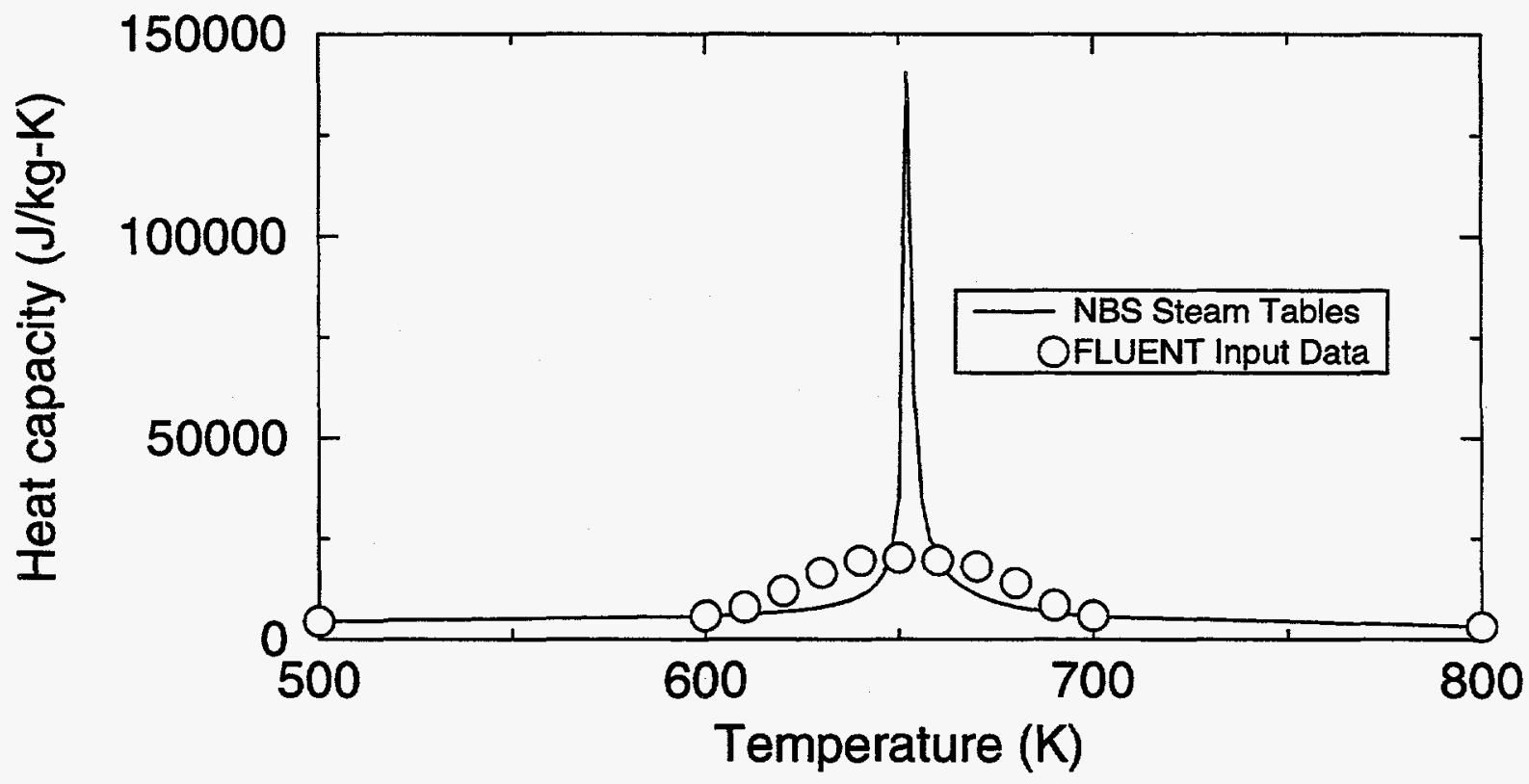

Figure 6. Comparison of water specific heat calculated from NBS steam tables with the approximation used in FLUENT model at 3500 psia and near the critical temperature of $652 \mathrm{~K}$. 


\section{FLOW SHEET SIMULATION}

The SCWO process was simulated using ASPEN PLUS for the baseline and cases replacing $\mathrm{CO}_{2}$ in the quench stream and a feed stream. The baseline case was based on the MODAR flow sheet with water used in the quench stream. The energy consumption in the baseline is compared with that for $\mathrm{CO}_{2}$ replacement in the quench stream and a partial replacement in the feed stream.

The mass flow used in this simulation was obtained from MODAR and was scaled up by a factor of 10 because we wanted to evaluate a larger scale than the MODAR's pilot scale.

The basis for and assumptions used in the simulations presented in Section 4 are given below. As additional data are obtained for different equipment or should assumptions regarding operation of the flow sheet be modified, the simulations can easily be rerun.

\subsection{Basis for Feeds}

\subsubsection{Air}

$2037 \mathrm{lb} / \mathrm{hr}(467.2 \mathrm{ACFM}, 434.4 \mathrm{SCFM}), 21 \mathrm{vol} \% \mathrm{O}_{2} / 79 \% \mathrm{~N}_{2}$ or $23.2 \mathrm{wt} \% \mathrm{O}_{2} / 76.8 \% \mathrm{~N}_{2}$.

\subsubsection{Water}

$70^{\circ} \mathrm{F}$ from storage tank, $14.7 \mathrm{psia}$.

Supercritical water $-155 \mathrm{lb} / \mathrm{hr}$ (Baseline)

$-2585 \mathrm{lb} / \mathrm{hr}$ (Case-A)

$-2869 \mathrm{lb} / \mathrm{hr}$ (Case-B)

Quench water (Baseline) - $5950 \mathrm{lb} / \mathrm{hr}$ to set the reaction effluent temperature at less than $540^{\circ} \mathrm{F}$.

Water to brine pool $-265 \mathrm{lb} / \mathrm{hr}$.

\subsubsection{Simulated Waste}

Isopropyl Alcohol - $165 \mathrm{lb} / \mathrm{hr}, 70^{\circ} \mathrm{F}, 14.7 \mathrm{psia}$.

\subsubsection{Simulated Impurities}

Sodium Chloride $-0.1 \mathrm{lb} / \mathrm{hr}, 70^{\circ} \mathrm{F}, 14.7 \mathrm{psia}$ 


\subsubsection{Pressure profile}

The outlet pressure of all high pressure pumps and the air compressor was assumed to be 3600 psia, the outlet of the SCWO reactor 3500 psia, the first stage separator 1500 psia, the second stage separator $100 \mathrm{psia}$, and the evaporator $14.7 \mathrm{psia}$.

\subsubsection{Air Compressor}

The air compressor was simulated as 4-stage compressor with intercoolers on the first three stages only, cooling air to a temperature of $100^{\circ} \mathrm{F}$.

\subsubsection{Temperatures}

Baseline: Inner nozzle $-100^{\circ} \mathrm{F}$
Outer nozzle $-1112^{\circ} \mathrm{F}$
Case-A: Inner nozzle $-122^{\circ} \mathrm{F}$
Outer nozzle $-930^{\circ} \mathrm{F}$
Case-B: Inner nozzle $-123^{\circ} \mathrm{F}$
Outer nozzle $-1012^{\circ} \mathrm{F}$
Reactor outlet: $1112^{\circ} \mathrm{F}\left(600^{\circ} \mathrm{C}\right)$
Evaporator: $212^{\circ} \mathrm{F}$
Quench stream: $<540^{\circ} \mathrm{F}$

\subsubsection{Equation of State Used}

The ASME steam table, STEAM-TA, was used for all water streams. The Peng-Robinson cubic equation of state was used for the SCWO reactor and NRTL-RK, also known as the Renon model, for the liquid phase, the Redlich-Kwong equation of state for the gas phase, and Henry's law for supercritical components. The NRTK-RK was used in all the separators where the pressure is much less than that for the reactor.

\subsection{Baseline Simulation}

The MODAR pilot scale flow sheet is shown in Reference 7 . Stream 1 is air at $70 \mathrm{~F}$ and ambient temperature. Air then is compressed at 3598 psia and $475^{\circ} \mathrm{F}$ and is combined with water from stream 2. These streams are preheated at B13 and enter the SCWO reactor through the outer nozzle. Stream 3 is isopropyl alcohol (IPA) and is combined with water from stream 2 . They enter the SCWO reactor through the inner nozzle. The SCWO reactor is operated at 3500 psia and $1112^{\circ} \mathrm{F}$. B23 is a splitter where the reaction effluents are removed and fed to B32, the brine is mixed with cold water injection from stream 4 and is fed to SEP3, the medium pressure separator via a cooler, B27.

The reaction effluents, $\mathrm{CO}_{2}$ and water, are quenched with cold water from stream 5 at $\mathrm{B} 32$. 
MODAR wants to maintain the mixed temperature at less than $572^{\circ} \mathrm{F}\left(300^{\circ} \mathrm{C}\right)$. The quenched stream then is fed through a heat exchanger to reduce the temperature to $100^{\circ} \mathrm{F}$ before it enters SEP1, the first separator. The first separator is a high pressure separator (1500 psia) to separate the gas and liquid at that condition. Approximately $80 \%$ of the $\mathrm{CO}_{2}$ is removed from this separator via the top, which goes to the atmosphere. Most of the water and remaining $\mathrm{CO}_{2}$ goes to the second separator, the medium pressure separator, where the remaining $\mathrm{CO}_{2}$ is removed from the top, and water and residues are separated from the bottom. If the liquid stream contains impurities, e.g., $\mathrm{NaCl}$ for this simulation, the impurities are separated at the evaporator. In the MODAR process, the impurities are recycled back to the SCWO feed stream. However, in this study an evaporator was added to remove the impurities and determine the energy consumption.

\subsection{CASE-A Simulation}

Case- $\mathrm{A}$ is a $60 \%$ replacement of water by carbon dioxide in the feed stream, and one of the reaction products, carbon dioxide, is recycled to quench the reaction effluent stream.

Since the feed composition to the SCWO reactor is different than in the baseline case, the inlet enthalpy is changed. In order to maintain the reactor temperature at less than $600^{\circ} \mathrm{C}$, the inlet stream temperature needs to be calculated. This enthalpy calculation was performed using the enthalpy equation as described in Section 3.

As shown in Figure 8 in Section 5, carbon dioxide, a reaction product, is separated at the first separator, SEP1, and is recycled to quench the hot reaction effluents to $521^{\circ} \mathrm{F}$. Before the carbon dioxide is fed to the first separator, the air and carbon dioxide are separated in block B2. The separation unit, B2, could be a membrane separator. Parametric studies on removing carbon dioxide from the air and combustion gases indicate that membrane separation is feasible existing plant technology.

\subsection{CASE-B Simulation}

The Case-B simulation is very similar to that of the Case-A simulation. The only difference is that Case-B condenses a $20 \%$ replacement of water by carbon dioxide in the feed stream vs. $40 \%$ for Case-A. The Case-B simulation was performed prior to Case-A. However, it is presented in the later section. The concept of using carbon dioxide in the quench stream is the same as the Case-A. 


\section{SIMULATION RESULTS}

Results for three cases are shown in the following flow sheets, together with tables for each case. The flow sheets show the unit operations with flow rates, temperatures, pressures, heat/ cooler duties and pump horsepower. Stream component and fow rates are given on material balance tables following each flow sheet. The cases shown include the baseline case (no $\mathrm{CO}_{2}$ ), Case$\mathrm{A}\left(40 \% \mathrm{CO}_{2}\right.$ in the core feed), and Case- $\mathrm{B}\left(20 \% \mathrm{CO}_{2}\right.$ in the core feed).

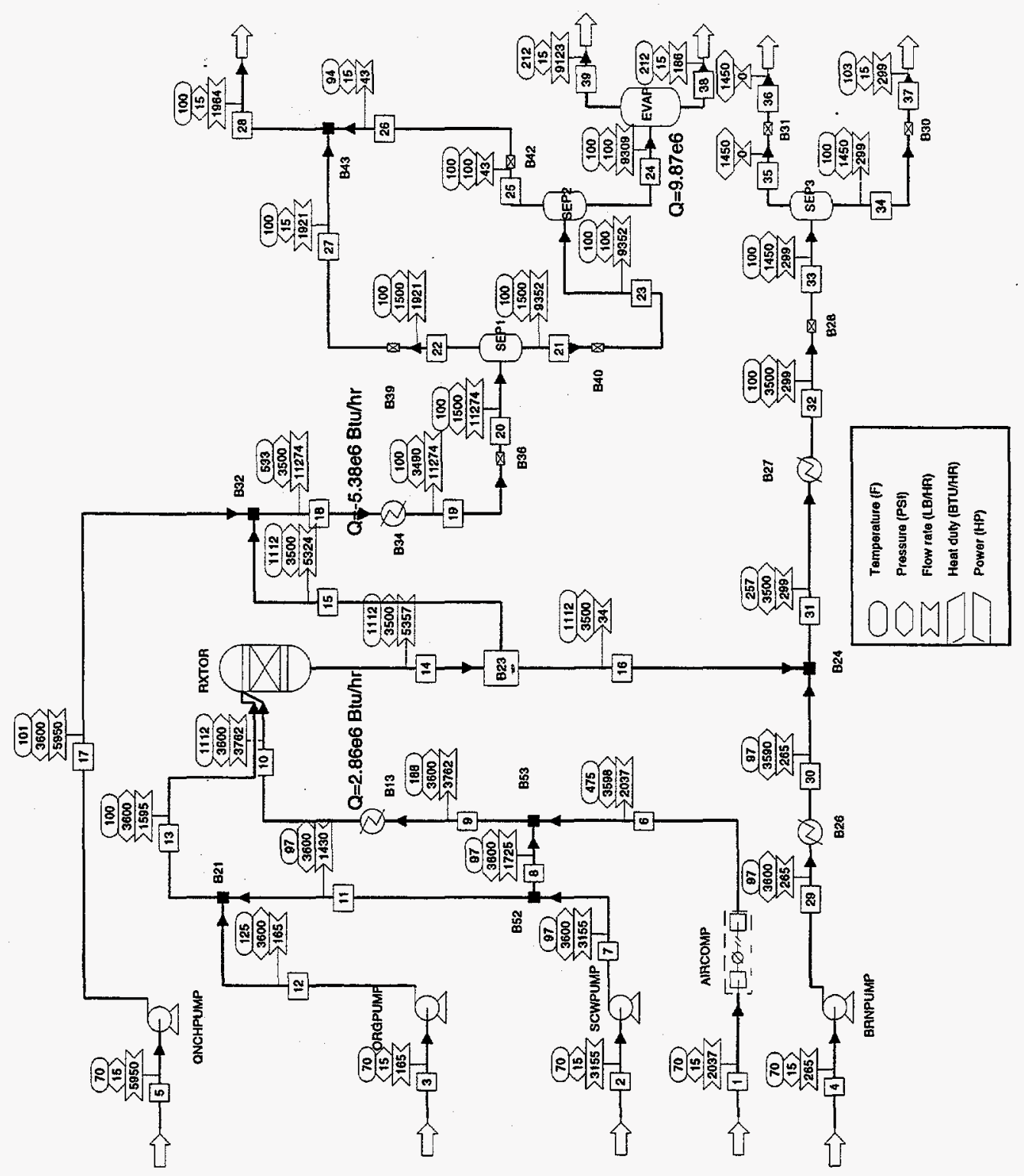

Figure 7. SCWO Flow Sheet for Baseline Case. 


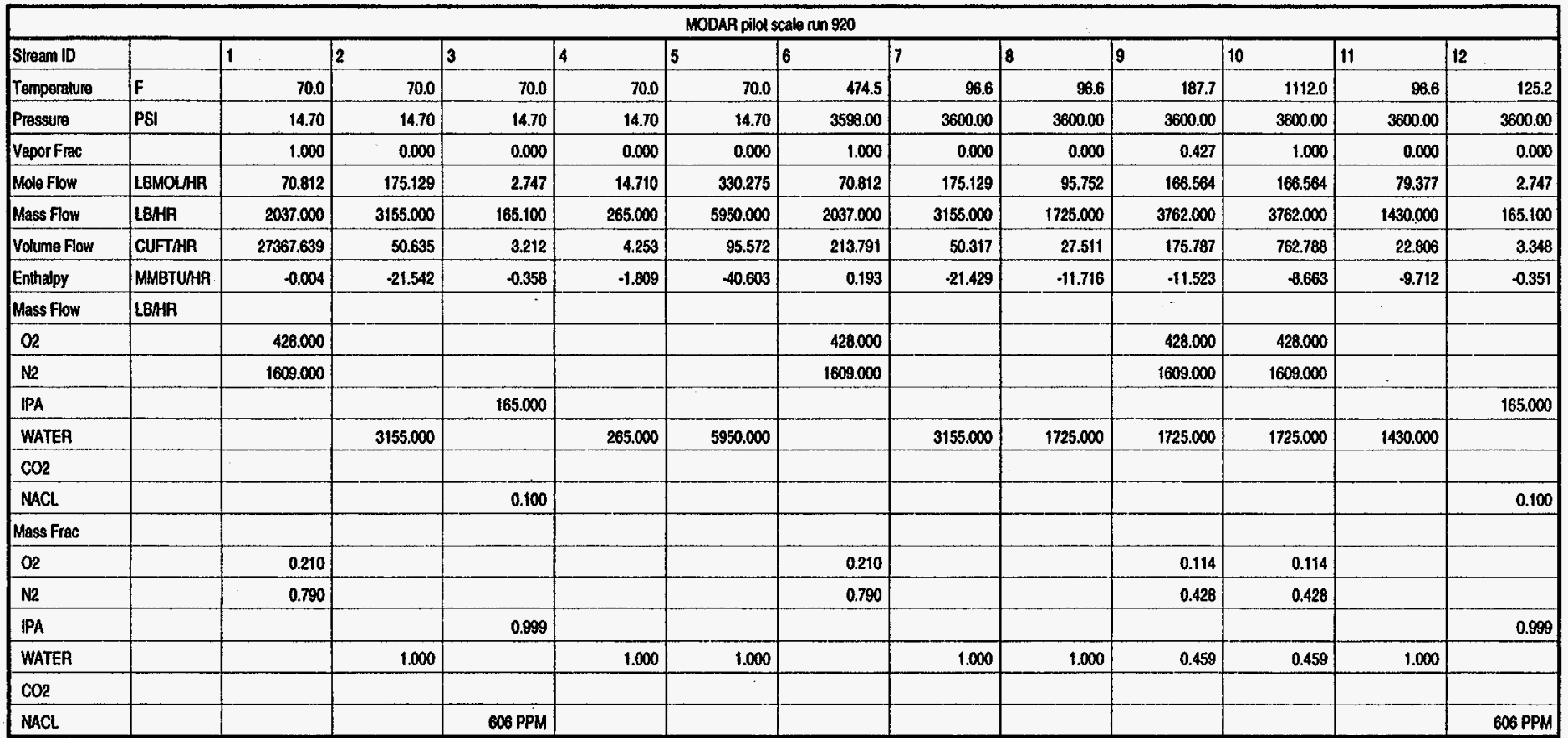




\begin{tabular}{|c|c|c|c|c|c|c|c|c|c|c|c|c|c|}
\hline \multicolumn{14}{|c|}{ MODAR pilot scale nun 920} \\
\hline Stream ID & & 13 & 114 & 15 & 16 & 17 & 18 & 19 & 20 & 21 & 22 & 23 & 24 \\
\hline Pressure & PSI & 3600.00 & 3500.00 & 3500.00 & 3500.00 & 3600.00 & 3500.00 & 3490.00 & 1500.00 & 1500.00 & 1500.00 & 100,00 & 100.00 \\
\hline Mole Flow & LEMOLHR & 82.124 & 252.807 & 250.946 & 1.861 & 330.275 & 581.221 & 561.221 & 581.221 & 516.521 & 64.700 & 516.521 & 515.381 \\
\hline Mass Flow & LBHA & 1595.100 & 5357.100 & 5323.571 & 33.529 & 5950.000 & 11273.571 & 11273.571 & 11273.571 & 9352.322 & 1921.249 & 9352.322 & 9309.240 \\
\hline Volume Flow & CUFTMR & 26.577 & 1139.452 & 1131.701 & 7.621 & 97.191 & 500.113 & 265.031 & 403.634 & 152.540 & 251.094 & 219.130 & 151.860 \\
\hline 02 & & & 32.647 & 32.647 & & & 32.647 & 32.647 & 32.647 & 0.445 & 32.202 & 0.445 & 0.025 \\
\hline N2 & & & 1609.000 & 1609.000 & & & 1609.000 & 1609.000 & 1609.000 & 11.973 & 1597.027 & 11.973 & 0.360 \\
\hline IPA & & 165.000 & & & & & & & & & & & \\
\hline WATER & & 1430.000 & 3352.852 & 3319.323 & 33.529 & 5950.000 & 9269.323 & 9269.323 & 9269.323 & 9267.817 & 1.506 & 9267.817 & 9267:609 \\
\hline $\mathrm{CO} 2$ & & & 362.501 & 362.501 & & & 362.501 & 362.501 & 362.501 & 71.987 & 290.515 & 71.987 & 41.146 \\
\hline NACL & & 0.100 & 0.100 & 0.100 & & & 0.100 & 0.100 & 0.100 & 0.100 & & 0.100 & 0.100 \\
\hline WATER & & 0.896 & 0.626 & 0.624 & 1.000 & 1.000 & 0.822 & 0.822 & 0.822 & 0.991 & 784 PPM & 0.991 & 0.996 \\
\hline $\mathrm{CO} 2$ & & & 0.068 & 0.068 & & & 0.032 & 0.032 & 0.032 & 0.008 & 0.151 & 0.008 & 0.004 \\
\hline NACL & & $63 \mathrm{PPM}$ & $19 \mathrm{PPM}$ & $19 \mathrm{PPM}$ & & & 9 PPM & 9PPM & 9PPM & $11 \mathrm{PPM}$ & & 11 PPM & $11 \mathrm{PPM}$ \\
\hline
\end{tabular}




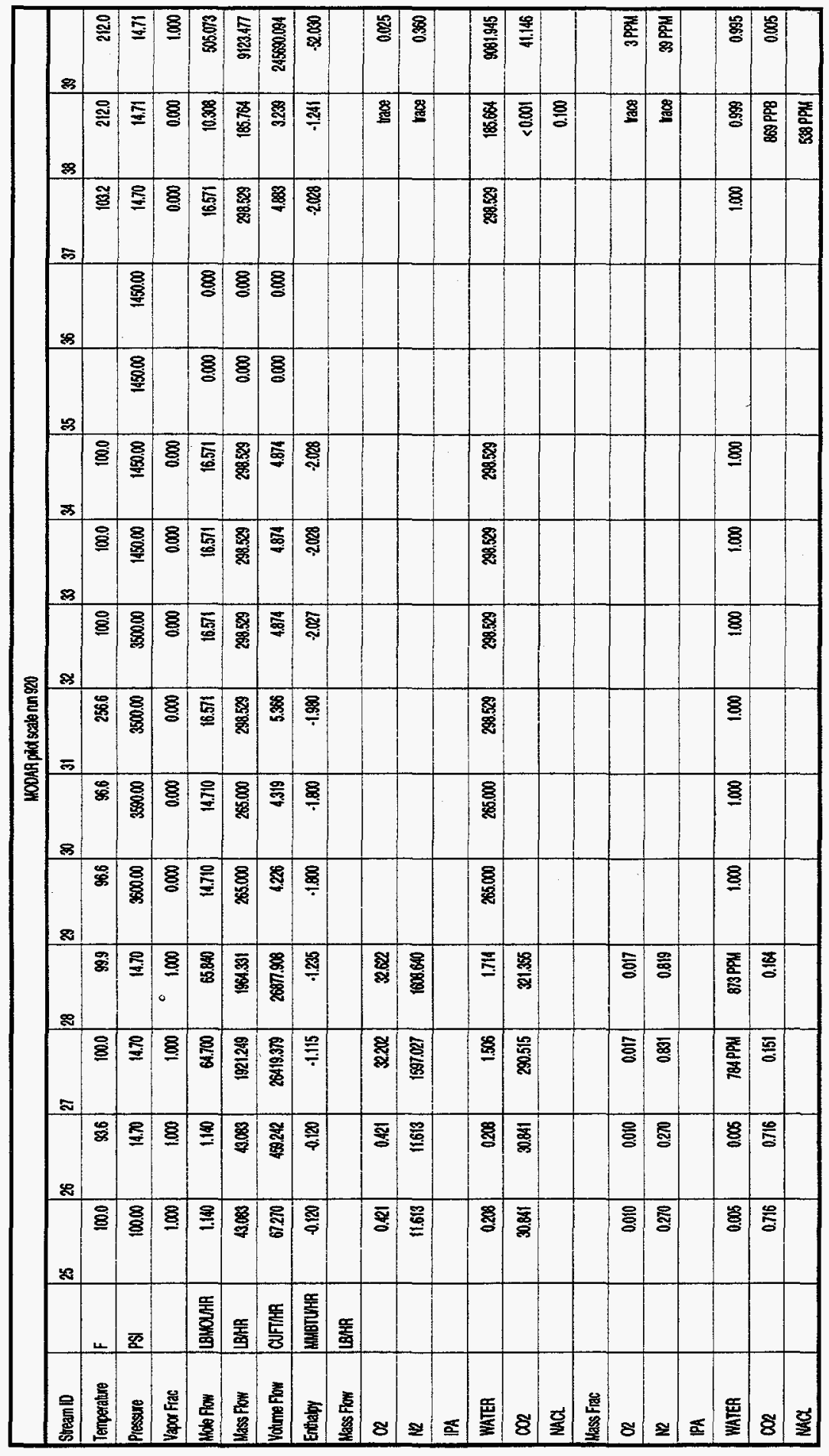




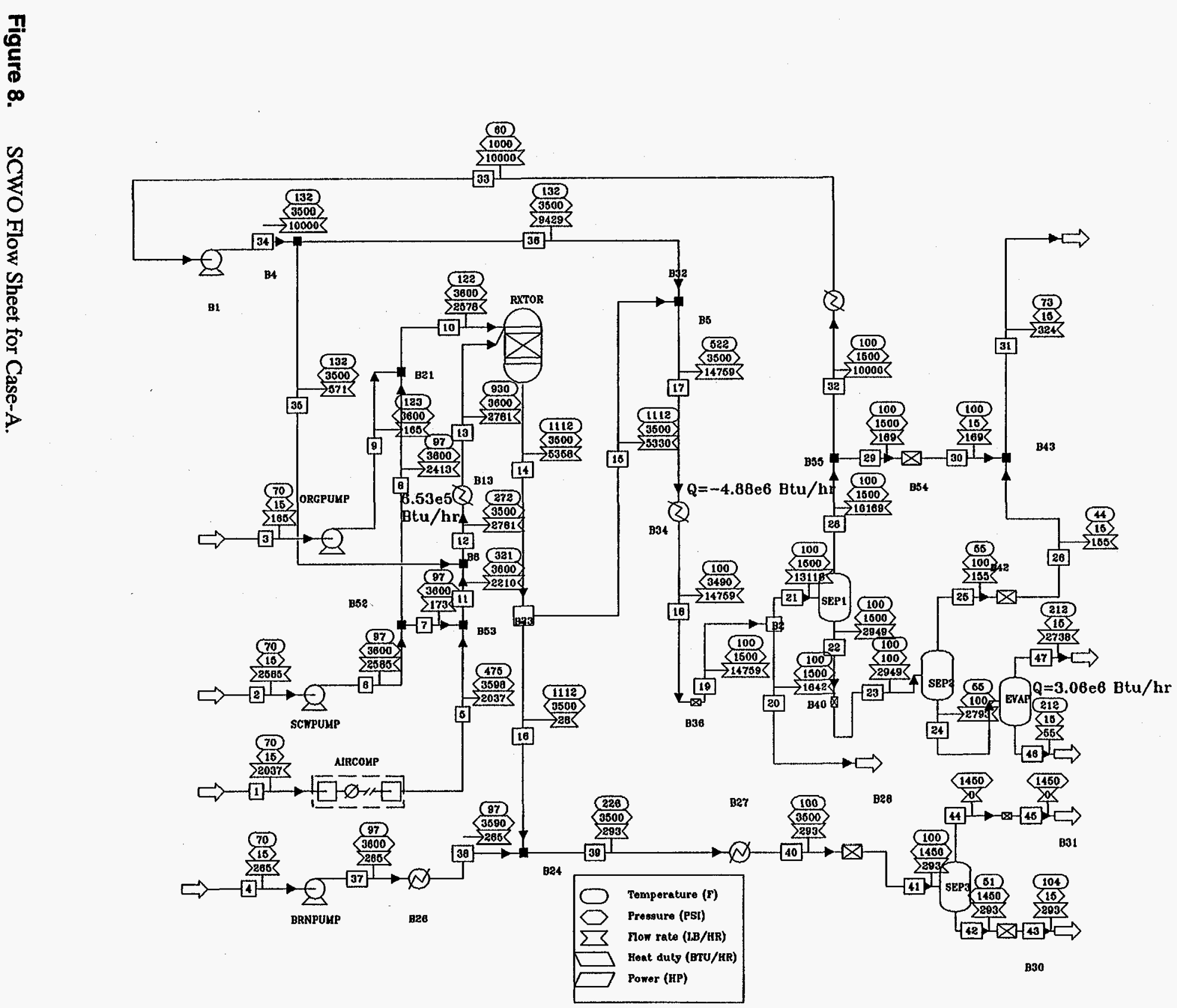




\begin{tabular}{|c|c|c|c|c|c|c|c|c|c|c|c|c|c|}
\hline \multicolumn{14}{|c|}{$60 \%$ SCW and $40 \%$ cO2 in the Core Foed } \\
\hline Stroam ID & & 1 & 2 & 3 & 14 & 5 & 6 & 7 & 8 & 9 & 10 & 11 & 12 \\
\hline From & & & & & & AARCOMP & SCWPUMP & 852 & 852 & ORGPUMP & B21 & $B 53$ & B6 \\
\hline To & & AIRCOMP & SCWPUMP & ORGPUMP & BANPUMP & 853 & 852 & 853 & 821 & B21 & RXTOR & $B 6$ & $B$ 13 \\
\hline Phase & & VAPOR & LLOUID & LIOUID & LIQUID & VAPOR & LLaUid & LLOUID & LLOUID & LOVUID & LIOUID & MIXED & MIXED \\
\hline \multicolumn{14}{|c|}{ Substream: MIXED } \\
\hline Mass Flow & LBNAR & & & & & & & & & & & & \\
\hline 02 & & 428.0000 & 0.0 & 0.0 & 0.0 & 428.0000 & 0.0 & 0.0 & 0.0 & 0.0 & 0.0 & 428.0000 & 428.0000 \\
\hline $\mathrm{N}_{2}$ & & 1609.000 & 0.0 & 0.0 & 0.0 & 1609.000 & 0.0 & 0.0 & 0.0 & 0.0 & 0.0 & 1609.000 & 1609.000 \\
\hline IPA & & 0.0 & 0.0 & 165.0000 & 0.0 & 0.0 & 0.0 & 0.0 & 0.0 & 165.0000 & 165.0000 & 0.0 & 0.0 \\
\hline WATER & & 0.0 & 2585.000 & 0.0 & 265.0000 & 0.0 & 2585.000 & 172.5000 & 2412.500 & 0.0 & 2412.500 & 172.5000 & 173.1389 \\
\hline $\mathrm{CO} 2$ & & 0.0 & 0.0 & 0.0 & 0.0 & 0.0 & 0.0 & 0.0 & 0.0 & 0.0 & 0.0 & 0.0 & 570.3611 \\
\hline NACL & & 0.0 & 0.0 & .1000000 & 0.0 & 0.0 & 0.0 & 0.0 & 0.0 & .1000000 & .1000000 & 0.0 & 0.0 \\
\hline \multicolumn{14}{|l|}{ Mass Frac } \\
\hline 02 & & .2101129 & 0.0 & 0.0 & 0.0 & 2101129 & 0.0 & 0.0 & 0.0 & 0.0 & 0.0 & .1937090 & .1539291 \\
\hline \begin{tabular}{|l|}
$N_{2}$ \\
\end{tabular} & & .7898871 & 0.0 & 0.0 & 0.0 & 7898871 & 0.0 & 0.0 & 0.0 & 0.0 & 0.0 & .7282190 & .5786729 \\
\hline IPA & & 0.0 & 0.0 & .9993943 & 0.0 & 0.0 & 0.0 & 0.0 & 0.0 & .9993943 & .0640130 & 0.0 & 0.0 \\
\hline WATER & & 0.0 & 1.000000 & 0.0 & 1.000000 & 0.0 & 8.000000 & 1.000000 & 1.000000 & 0.0 & .8359482 & .0780719 & .0622689 \\
\hline $\mathrm{CO} 2$ & & 0.0 & 0.0 & 0.0 & 0.0 & 0.0 & 0.0 & 0.0 & 0.0 & 0.0 & 0.0 & 0.0 & 2051290 \\
\hline MACL & & 0.0 & 0.0 & $6.05694 E-4$ & 0.0 & 0.0 & 0.0 & 0.0 & 0.0 & $6.056945-4$ & $\mathbf{3 . 8 7 9 5 8 E - 5}$ & 0.0 & 0.0 \\
\hline Total flow & LBMOLNR & 70.81213 & 143.4898 & 2.747322 & 14.70973 & 70.81213 & 143.4893 & 9.575205 & 133.9141 & 2.747322 & 136.6614 & 80.38734 & 93.38267 \\
\hline Total fow & LBAR & 2037.000 & 2685.000 & 165.1000 & 265.0000 & 2037.000 & 2585.000 & 172.5000 & 2412.500 & 165.1000 & 2677.600 & 2009.500 & 2760.500 \\
\hline Total flow & CUFTMA & 27365.48 & $41.48 \mathrm{AB} 6$ & 3.212387 & 4.252996 & 215.4203 & 41.22650 & 2.751091 & 38.47541 & 3.342847 & 43.15127 & 186.4909 & 201.9247 \\
\hline Temperature & $F$ & 70.00000 & 70.00000 & 70.00000 & 70.00000 & 474.5000 & 96.64977 & 96.04977 & 96.6497 & 123.3087 & 121.5794 & 321.1481 & 271.6769 \\
\hline Prossure & PSI & 14.70000 & 14.70000 & 14.70000 & 14.70000 & 3598.000 & 3600.000 & 3600.000 & 3600.000 & 3600.000 & 3600.000 & 3600.000 & 3500.000 \\
\hline Vapor Frac & & 1.000000 & 0.0 & 0.0 & 0.0 & 1.000000 & 0.0 & 0.0 & 0.0 & 0.0 & 0.0 & .9249574 & .9220318 \\
\hline Liquild Frac & & 0.0 & 1.000000 & 1.000000 & 1.000000 & 0.0 & 1.000000 & 1.000000 & 1.000000 & 1.000000 & 1.000000 & .0750426 & .0779682 \\
\hline Sold Frac & & 0.0 & 0.0 & 0.0 & 0.0 & 0.0 & 0.0 & 0.0 & 0.0 & 0.0 & 0.0 & 0.0 & 0.0 \\
\hline Enthalpy & BTURBAOL & 52.34120 & $-1.2301 \mathrm{E}+5$ & $-1.2958 E+5$ & $-1.2301 E+5$ & 2723.120 & $-1.2236 \mathrm{E}+5$ & $-1.2236 \mathrm{E}+5$ & $-1.2236 \mathrm{E}+5$ & $-1.2695 \mathrm{E}+5$ & $-1.2245 E+5$ & -12175.78 & -34534.51 \\
\hline Enthalpy & BTURB & -1.819535 & -6827.949 & -2156.184 & .6827 .949 & 94.66370 & 6791.935 & -6791.935 & -6791.935 & -2112.522 & 6492.209 & .442 .9865 & -1159.836 \\
\hline Enthalpy & BTUAR & 3706.392 & $-1.7650 E+7$ & $3.5599 E+5$ & $-1.8094 E+6$ & $1.92830 E+5$ & $-1.7557 E+7$ & $-1.1716 \mathrm{E}+6$ & $-1.6386 \mathrm{E}+7$ & $3.4878 E+5$ & $-1.6734 E+7$ & $-9.7878 E+5$ & $3.2249 E+6$ \\
\hline Entropy & BTUREMOL-R & .8647316 & 39.20159 & -106.5672 & -39.20159 & -6.306702 & 38.36061 & 38.36061 & 38.36061 & .903 .3147 & 39.54467 & -9.820050 & -9.631158 \\
\hline Entropy & BTULB.A & .0300606 & -2.176019 & -1.773316 & -2.176019 & .2192396 & -2.129338 & -2.129338 & -2.129338 & -1.719193 & -2.096613 & .3572789 & .3234610 \\
\hline Density & LBMOUCUFT & 2.58765E-3 & 3.458677 & .8552278 & 3.45867 & .3287162 & 3.480512 & 3.480512 & 3.480512 & .8218508 & 3.167031 & .4310523 & .4624628 \\
\hline Density & LBICUFT & .0744360 & 62.30904 & 51.39489 & 62.30904 & 8.455933 & 62.70240 & 62.70240 & 62.70240 & 49.38903 & 59.73405 & 11.84776 & 13.76999 \\
\hline Average MW & & 28.76628 & 18.01528 & 60.09489 & 18.01628 & 28.76626 & 18.01528 & 18.01528 & 18.01528 & 60.09489 & 18.86121 & 27.48567 & 29.77533 \\
\hline
\end{tabular}




\begin{tabular}{|c|c|c|c|c|c|c|c|c|c|c|c|c|c|}
\hline \multicolumn{14}{|c|}{ 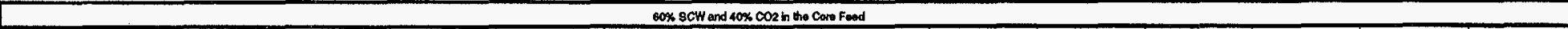 } \\
\hline Stroam ID & & 13 & 11 & 15 & 118 & 17 & 10 & 10 & 20 & 21 & 21 & 23 & 24 \\
\hline From & & Bis & PXTOR & 823 & 823 & B32 & Das & B36 & 82 & 82 & 82 & 240 & SEP2 \\
\hline To & & AXYOR & B23 & B32 & 824 & 834 & 838 & $B_{2}$ & & SEP1 & SEPI & SEP2 & EVAP \\
\hline Phase & & VAPOR & MXED & MIXED & VAPOA & MIXED & MIEED & MIXED & VAPOR & MIXED & MXED & MIXEO & uoulo \\
\hline \multicolumn{14}{|c|}{ Suthostrom: M MIXED } \\
\hline Mass form & LЕRА & & & & & & & & & & & & \\
\hline 02 & & 426.0000 & $32.646 \mathrm{sg}$ & 32.06689 & 0.0 & 32.64669 & 32.64689 & 32.64689 & 32.84689 & 0.0 & 0.0 & 0.0 & 0.0 \\
\hline $\mathrm{N}_{2}$ & & 1800.0000 & 1809.000 & 1600.000 & 0.0 & 1609.000 & 1609.000 & 16008.000 & .1600 .000 & 0.0 & 0.0 & 0.0 & 0.0 \\
\hline IPA & & 0.0 & 0.0 & 0.0 & 0.0 & 0.0 & 0.0 & 0.0 & 0.0 & 0.0 & 0.0 & 0.0 & 0.0 \\
\hline WATER & & 173.1999 & 2783.491 & 2755.056 & 27.83491 & 2766.208 & 2768.206 & 2766.206 & 0.0 & 2768.208 & 2766.206 & 2754.927 & 2754.6800 \\
\hline $\cos 2$ & & 670.38611 & 2022.8625 & 932.8625 & 0.0 & 10351.31 & 10351.31 & 10351.31 & 0.0 & 10351.31 & 10351.31 & 180.7000 & 38.70785 \\
\hline NACL & & 0.0 & .1000000 & .0000000 & 0.0 & .0000000 & .0000000 & .10000000 & 0.0 & .0000000 & .10000000 & .0990999 & 09999898 \\
\hline \multicolumn{14}{|l|}{ Mases Frac } \\
\hline O2 & & .15998291 & $8.09500 \mathrm{E}-\mathrm{S}$ & $8.12482 E-3$ & 0.0 & $2.21180 E-3$ & $2.211866-3$ & $2.21196 \mathrm{E}-3$ & .01888686 & 0.0 & 0.0 & 0.0. & 0.0 \\
\hline $\mathrm{N}_{2}$ & & .5780728 & .3002390 & .0018812 & 0.0 & 1090163 & .1090163 & .000163 & .8801193 & 0.0 & 0.0 & 0.0 & 0.0 \\
\hline$I P A$ & & 0.0 & 0.0 & 0.0 & 0.0 & 0.0 & 0.0 & 0.0 & 0.0 & 0.0 & 0.0 & 0.0 & 0.0 \\
\hline WATER & & .0622698 & .5184921 & .5189829 & 1.000000 & 1874218 & .8774218 & .1872218 & 0.0 & 210877 & 21008771 & .8342772 & .98861078 \\
\hline$\infty \infty_{2}$ & & .2051220 & .1741032 & .1750124 & 0.0 & .7018444 & .7013434 & .7019434 & 0.0 & 78891159 & 7891163 & .0568918 & .01385654 \\
\hline NACL & & 0.0 & $1.86693 E-5$ & $1.87608 \mathrm{E}-5$ & 0.0 & $6.77541 E S$ & $6.77541 E-6$ & Q.RSA1E- & 0.0 & $7.62334 \mathrm{E}-\mathrm{A}$ & $7.6223840-6$ & $3.39141 \mathrm{E}-5$ & $3.57975 E-5$ \\
\hline Tolal Flow & LMMOLHA & 00.38287 & 234.1625 & 232.5174 & 1.545072 & 47.2111 & 477.2111 & 447.23111 & $60.4569 \theta$ & 388.7542 & 388.7542 & 167.9192 & 153.7992 \\
\hline Totad Flow & LQAHR & 2700.600 & 59568.100 & 6380.285 & 27.83491 & 14750.29 & 14759.28 & 14759.28 & 1841.647 & 13117.62 & 13117,62 & 2948.629 & 2703.488 \\
\hline Told firow & CUFTAR & 4129932 & 1102.758 & 1096.070 & 8.513201 & 1144.004 & 330.5548 & 799.9870 & 233.4406 & 305.71728 & $305.712 \mathrm{~g}$ & 301.8040 & 44.37844 \\
\hline Temporatums & $F$ & 830.0000 & 1112.000 & 1112.000 & 1112000 & 522.2865 & 100.0000 & 100.0000 & 100.0000 & 100.0000 & 1000.00000 & 100.0000 & 54.74842 \\
\hline Prosasurs & PSI & 3600.000 & 2500.0000. & 3500.000 & 3500.000 & 3500.000 & 3990.000 & 1500.000 & 1500.000 & 1500.0000 & 1500.000 & 100.0000 & 100.0000 \\
\hline Vaporfirias & & 1.0000000 & 9090 & .9595825 & 1.0000000 & .9999960 & .65933747 & .6577915 & 1.0000000 & .0078789 & .60787898 & .0281232 & 0.0 \\
\hline Ulquidf Frac & & 0.0 & $1.975286-6$ & $7.42407 E-6$ & 0.0 & 3.999735E- & 3406253 & .3422005 & 0.0 & .3921209 & .3921203 & .8718767 & 1.000000 \\
\hline Soldd Frac & & 0.0 & 0.0 & 0.0 & 0.0 & 0.0 & 0.0 & 0.0 & 0.0 & 0.0 & 0.0 & 0.0 & 0.0 \\
\hline Entalapy & GTUnEANOL & -27597.80 & .75960 .30 & .75823 .02 & .06856 .50 & $-1,2238 E+5$ & $-1.3329 E+5$ & $-1.3230 \mathrm{E}+\mathrm{S}$ & .96 .22006 & $-1.6327 E+5$ & $-1.6327 E+5$ & $-1.2453 E+5$ & $-1.2350 E+5$ \\
\hline Entraby & aturs & .025 .1889 & 3318.657 & -3308.983 & 5976.953 & 3708.099 & .4038 .647 & 1000.823 & 3.426289 & 4512.365 & -4542.365 & 6044.134 & 6799.110 \\
\hline Entraby & ตTUMR & $-2.5725 \mathrm{E}+6$ & $-1.7787 \mathrm{E}+7$ & $-1.7838 E+7$ & $-1.4965 E+5$ & $-5.47292 E+7$ & $-5.9607 E+7$ & $-5.9167 E, 7$ & .5624 .772 & $-5.9595 E+7$ & $-5.0595 E+7$ & - $1.9591 \mathrm{E}+7$ & $-1.8993 E+7$ \\
\hline Entropy & BTULBAOL-A & -2.5400000 & -7.558775 & .7 .5277 .57 & -13.21078 & 8.163911 & .22 .23990 & .18 .81704 & -9.142892 & .23 .95824 & 23.05624 & -30.25507 & -39.43235 \\
\hline Entropy & Bruhb-A & .0855418 & .03003376 & .3285048 & .77330965 & .2470065 & .67398772 & .0006634 & .3255664 & .7100222 & .7800272 & 2.041250 & 2.170915 \\
\hline Densily & LEMOLCUFT & .2284163 & 212348 & .2122288 & .2372216 & .3008100 & 1.352501 & .5883078 & .2504143 & 1.271632 & 1.271632 & .5214701 & 3.465560 \\
\hline Densiviy & LEMCUFT & 8.742515 & 4.055818 & 4.883070 & 4.273814 & 1280127 & 4.63647 & 10.87989 & 7.082395 & 4200031 & 12.0033 & 9.773698 & 62.94979 \\
\hline Average OWW & & 29.77333 & 22.06187 & 22.01130 & 18.01528 & 33.00291 & 39.00281 & 39.00291 & 28.03504 & 33.74271 & 39.7427 & 18.74287 & 18.16198 \\
\hline
\end{tabular}




\begin{tabular}{|c|c|c|c|c|c|c|c|c|c|c|c|c|}
\hline \multicolumn{13}{|c|}{$60 \% \mathrm{SCW}$ and $40 \%$ CO2 in the Core Feed } \\
\hline Stream 10 & & 25 & 26 & 28 & 29 & 30 & 31 & 32 & 33 & 34 & 35 & 36 \\
\hline Fram & & SEPR & 842 & SEP1 & B55 & B54 & B43 & B55 & B5 & B1 & B4 & $B 4$ \\
\hline To & & 842 & B43 & 855 & 854 & B43 & & 85 & B1 & B4 & B6 & 832 \\
\hline Phase & & VAPOR & VAPOR & VAPOR & VAPOR & VAPOR & VAPOR & VAPOA & LIQUID & LIOUID & LIQUID & LIOU: \\
\hline \multicolumn{13}{|c|}{ Substream: MIXED } \\
\hline Mass Flow & LQAR & & & & & & & & & & & \\
\hline 02 & & 0.0 & 0.0 & 0.0 & 0.0 & 0.0 & 0.0 & 0.0 & 0.0 & 0.0 & 0.0 & 0.0 \\
\hline N2 & & 0.0 & 0.0 & 0.0 & 0.0 & 0.0 & 0.0 & 0.0 & 0.0 & 0.0 & 0.0 & 0.0 \\
\hline IPA & & 0.0 & 0.0 & 0.0 & 0.0 & 0.0 & 0.0 & 0.0 & 0.0 & 0.0 & 0.0 & 0.0 \\
\hline WATER & & .1472212 & .1472212 & 11.37772 & .1890785 & .1690785 & .3362997 & 11.18864 & 11.18864 & 11.18864 & .6388716 & 10.54977 \\
\hline $\mathrm{CO} 2$ & & 154.9931 & 154.9931 & 10157.61 & 168.6024 & 168.8024 & 323.7954 & 9988.812 & 9988.812 & 9988.812 & 570.3611 & 9418.450 \\
\hline NACL & & 0.0 & 0.0 & 0.0 & 0.0 & 0.0 & 0.0 & 0.0 & 0.0 & 0.0 & 0.0 & 0.0 \\
\hline \multicolumn{13}{|l|}{ Mass Frac } \\
\hline 02 & & 0.0 & 0.0 & 0.0 & 0.0 & 0.0 & 0.0 & 0.0 & 0.0 & 0.0 & 0.0 & 0.0 \\
\hline N2 & & 0.0 & 0.0 & 0.0 & 0.0 & 0.0 & 0.0 & 0.0 & 0.0 & 0.0 & 0.0 & 0.0 \\
\hline IPA & & 0.0 & 0.0 & 0.0 & 0.0 & 0.0 & 0.0 & 0.0 & 0.0 & 0.0 & 0.0 & 0.0 \\
\hline WATER & & $9.48955 E-4$ & 9.48955E-4 & $1.11886 E-3$ & $1.11866 \mathrm{E}-3$ & 1.11886E-3 & $1.09754 \mathrm{E}-3$ & $1.11896 \mathrm{E}-3$ & $1.11886 \mathrm{E}-3$ & $1.11886 E-3$ & $1.11886 \mathrm{E}-3$ & $1.11886 E-3$ \\
\hline $\mathrm{CO} 2$ & & .8900510 & .8990510 & .9988812 & .9988812 & .9988812 & .9989625 & .9988812 & .9988812 & .9988812 & .9988812 & .9988812 \\
\hline NACL & & 0.0 & 0.0 & 0.0 & 0.0 & 0.0 & 0.0 & 0.0 & 0.0 & 0.0 & 0.0 & 0.0 \\
\hline Total Flow & LEMOLNAR & 3.529958 & 3.529958 & 231.4350 & \begin{tabular}{|l|}
.846059 \\
\end{tabular} & 3.846059 & 7.376016 & 227.5890 & 227.5890 & 227.5890 & 12.99533 & 214.5936 \\
\hline Total Flow & LBAHA & 155.1403 & 155.1403 & 10168.99 & 168.9914 & 168.9914 & 324.5317 & 10000.00 & 10000,00 & 10000.00 & 571.0000 & 9429.000 \\
\hline Total Flow & CUFTHR & 187.2278 & 1288.934 & $5+3.0027$ & 8.525237 & 1563.710 & 2054.346 & 504.4774 & 194.4409 & 340.2165 & 19.42636 & 320.7901 \\
\hline Temperature & $F$ & 54.74842 & 43.90178 & 100.0000 & 100.0000 & 100.0000 & 73.44510 & 100.0000 & 60.00000 & 131.6183 & 131.6183 & 131.6183 \\
\hline \begin{tabular}{|l|} 
Pressure \\
\end{tabular} & PSI & 100.0000 & 14.70000 & 1500.000 & 1500.000 & 14.70000 & 14.70000 & 1500.000 & 1000.000 & 3500.000 & 3500.000 & 3500.000 \\
\hline Vapor Frac & & 1.000000 & 1.000000 & 1.000000 & 1.000000 & 1.000000 & 1.000000 & 1.000000 & 0.0 & 0.0 & 0.0 & 0.0 \\
\hline Liquid Frac & & 0.0 & 0.0 & 0.0 & 0.0 & 0.0 & 0.0 & 0.0 & 1.000000 & 1.000000 & 1.000000 & 1.000000 \\
\hline Solid Frac & & 0.0 & 0.0 & 0.0 & 0.0 & 0.0 & 0.0 & 0.0 & 0.0 & 0.0 & 0.0 & 0.0 \\
\hline Enthalpy & BTULBMOL & $-1.6934 E+5$ & $-1.6934 E+5$ & $-1.7098 E+5$ & $-1.7098 E+5$ & $-1.6881 E+5$ & $-1.6906 \mathrm{E}+5$ & $-1.7098 E+5$ & $-1.7405 E+5$ & $-1.7284 E+5$ & $-1.7284 E+5$ & $-1.7284 E+5$ \\
\hline Enthapy & Втилв & -3853.011 & -3853.011 & -3891.371 & -3891.371 & -3841.962 & -3847.250 & .3891 .371 & .3961 .166 & .3938 .706 & .3933 .706 & -3933.706 \\
\hline Enthalpy & ETU/HR & $-5.8776 E+5$ & $-5.9776 E+5$ & $-3.9571 E+7$ & $-6.5761 E+5$ & $-6.4926 \mathrm{E}+5$ & $-1.2470 E+6$ & $.3 .8914 E+7$ & $-3.9612 E+7$ & $\cdot .3 .9337 E+7$ & $-2.2461 E+6$ & $3.7091 \mathrm{E}+7$ \\
\hline Entropy & BTU/.9MOL.R & .3 .631488 & .1097827 & .10 .69097 & -10.89097 & 1.050977 & .6129321 & -10.69097 & .16 .18714 & .14 .74262 & -14.74262 & -14.74262 \\
\hline Entropy & BTURB-A & -.0026284 & $2.49792 E-3$ & -.2433147 & .2433147 & .0239190 & .0139480 & .2433147 & .3694014 & .3355258 & .3355258 & -.2355258 \\
\hline Density & LEMOLICUFT & .0188538 & $2.73867 \mathrm{E}-3$ & .4511380 & .4511380 & $2.45957 \mathrm{E}-3$ & $2.58414 E-3$ & .4511380 & 1.170479 & .6689534 & .6689534 & .6669534 \\
\hline Density & LB/CUFT & .8286177 & .1203633 & 19.82249 & 19.82249 & .1080708 & .1135573 & 19.82249 & 51.42951 & 29.39305 & 29.39305 & 29.39305 \\
\hline Average MW & & 43.84962 & 43.94962 & 43.93887 & 43.93887 & 43.93887 & 43.94401 & 43.93887 & 43.93887 & 43,93887 & 43.93887 & 43.23887 \\
\hline
\end{tabular}




\begin{tabular}{|c|c|c|c|c|c|c|c|c|c|c|c|c|}
\hline \multicolumn{13}{|c|}{$60 \%$ SCW and $40 \%$ CO2 in the Core Feed } \\
\hline Stream ID & & 37 & 38 & 39 & 40 & 41 & 42 & 43 & 44 & 45 & 46 & 47 \\
\hline From & & BRNPUMP & B28 & B24 & B27 & B28 & SEP3 & $B 30$ & SEP3 & B31 & EVAP & EVAP \\
\hline To & & B26 & B24 & B27 & B28 & SEP3 & B30 & & B31 & & & \\
\hline Phase & & LlQuilo & LIOUID & Lould & LIOUID & LLOU1D & Llavid & LLOUID & MISSING & MISSING & Llavio & VAPOR \\
\hline \multicolumn{13}{|c|}{ Substroam: MIXEO } \\
\hline Mass Flow & LBAHR & & & & & & & & & & & \\
\hline 02 & & 0.0 & 0.0 & 0.0 & 0.0 & 0.0 & 0.0 & 0.0 & 0.0 & 0.0 & 0.0 & 0.0 \\
\hline N2 & & 0.0 & 0.0 & 0.0 & 0.0 & 0.0 & 0.0 & 0.0 & 0.0 & 0.0 & 0.0 & 0.0 \\
\hline IPA & & 0.0 & 0.0 & 0.0 & 0.0 & 0.0 & 0.0 & 0.0 & 0.0 & 0.0 & 0.0 & 0.0 \\
\hline WATER & & 265.0000 & 265.0000 & 292.8349 & 292.8349 & 292.8349 & 292.8349 & 292.8349 & 0.0 & 0.0 & 55,38022 & 2699.300 \\
\hline $\mathrm{CO2}$ & & 0.0 & 0.0 & 0.0 & 0.0 & 0.0 & 0.0 & 0.0 & 0.0 & 0.0 & $1.52451 E-4$ & 38.70770 \\
\hline NACL. & & 0.0 & 0.0 & 0.0 & 0.0 & 0.0 & 0.0 & 0.0 & 0.0 & 0.0 & .0999999 & 0.0 \\
\hline \multicolumn{13}{|l|}{ Mass Frac } \\
\hline 02 & & 0.0 & 0.0 & 0.0 & 0.0 & 0.0 & 0.0 & 0.0 & & & 0.0 & 0.0 \\
\hline $\mathrm{N}_{2}$ & & 0.0 & 0.0 & 0.0 & 0.0 & 0.0 & 0.0 & 0.0 & & & 0.0 & 0.0 \\
\hline IPA & & 0.0 & 0.0 & 0.0 & 0.0 & 0.0 & 0.0 & 0.0 & & & 0.0 & 0.0 \\
\hline WATER & & 1.000000 & 1.000000 & 1.000000 & 1.000000 & 1,000000 & 1.000000 & 1.000000 & & & .9981948 & .9856628 \\
\hline $\mathrm{CO} 2$ & & 0.0 & 0.0 & 0.0 & 0.0 & 0.0 & 0.0 & 0.0 & & & $2.74783 \mathrm{E}-6$ & .0141371 \\
\hline NACL & & 0.0 & 0.0 & 0.0 & 0.0 & 0.0 & 0.0 & 0.0 & & & $1.80244 E-3$ & 0.0 \\
\hline Total Flow & LBMOL/HA & 14.70973 & 14.70973 & 16.26481 & 16.25481 & 16.25481 & 16.25481 & 16.25481 & 0.0 & 0.0 & 3.075784 & 150.7134 \\
\hline Total Flow & LBAHR & 285.0000 & 265.0000 & 292.8349 & 202.6349 & 292.8349 & 292.8349 & 292.8349 & 0.0 & 0.0 & 56.48038 & 2738.007 \\
\hline Total Flow & CUFTHR & 4.226314 & 4.318507 & 5.155236 & 4.781085 & 4.781085 & 4.657605 & 4.790044 & 0.0 & 0.0 & .9657269 & 73049.22 \\
\hline Temperature & $F$ & 96.64977 & 96.60000 & 225.5032 & 100.0000 & 100.0000 & 51.40759 & 103.6749 & & & 212.0000 & 212.0000 \\
\hline Pressure & PSI & 3600.000 & 3590.000 & 3500.000 & 3500.000 & 1450.000 & $\mathbf{1 4 5 0 . 0 0 0}$ & 14.70000 & 1450.000 & 1450.000 & 14.76519 & 14.76519 \\
\hline Vapor Frac & & 0.0 & 0.0 & 0.0 & 0.0 & 0.0 & 0.0 & 0.0 & & & 0.0 & 1.000000 \\
\hline Lqquid Frac & & 1.000000 & 1.000000 & 1.000000 & 1.000000 & 1.000000 & 1.000000 & 1.000000 & & & 1.000000 & .0 .0 \\
\hline Solid Frac. & & 0.0 & 0.0 & 0.0 & 0.0 & 0.0 & 0.0 & 0.0 & & & 0.0 & 0.0 \\
\hline Enthalpy & BTURBMOL & $-1.2236 E+5$ & $-1.2314 E+5$ & $-1.2065 E+5$ & $-1.2308 E+5$ & $-1.2319 E+5$ & $-1.2319 \mathrm{E}+5$ & $-1.2319 E+5$ & & & $-1.2045 \mathrm{E}+5$ & $-1.0328 E+5$ \\
\hline Enthalpy & etun: & -6791.935 & -6835.546 & -6698.845 & -6832.148 & -6837.843 & 6837.849 & 6837.843 & & & -6677.984 & -5664.867 \\
\hline Enthalpy & BTUMAR & $-1.7999 E+6$ & $-1.8114 E+8$ & $-1.9611 E+6$ & $-2.0007 E+6$ & $-2.0024 E+6$ & $-2.0024 E+6$ & $-2.0024 E+6$ & & & $-3.7048 E+5$ & $-1.6565 E+7$ \\
\hline Entropy & BTURВMOL-R & .38 .36061 & -39.48794 & -35.43946 & -39.36005 & -39.31999 & -39.68830 & 39.15815 & & & -34.88838 & -8.677739 \\
\hline Entropy & BTURA-R & -2.129338 & -2.191914 & .1 .987189 & -2.185259 & -2.182591 & -2.203063 & -2.173608 & & & -1.934181 &. .4776855 \\
\hline Density & LQMOUCUFT & 3.480512 & 3.406209 & 3.153068 & 3.399816 & 3.399816 & 3.489949 & 3.392890 & & & 3.184942 & $2.06318 E-3$ \\
\hline Density & LB/CUFT & 62.70240 & 61.36380 & 56.80339 & 61.24863 & 61.24863 & 62.87242 & 61.12386 & & & 57.44934 & .0374816 \\
\hline Average MW & & 18.01528 & 18.01528 & 18.01528 & 18.01528 & 18.01628 & 18.01528 & 18.01528 & & & 18.03780 & 18.16698 \\
\hline
\end{tabular}




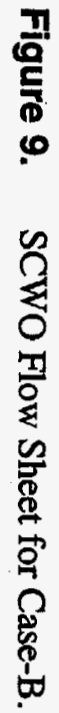

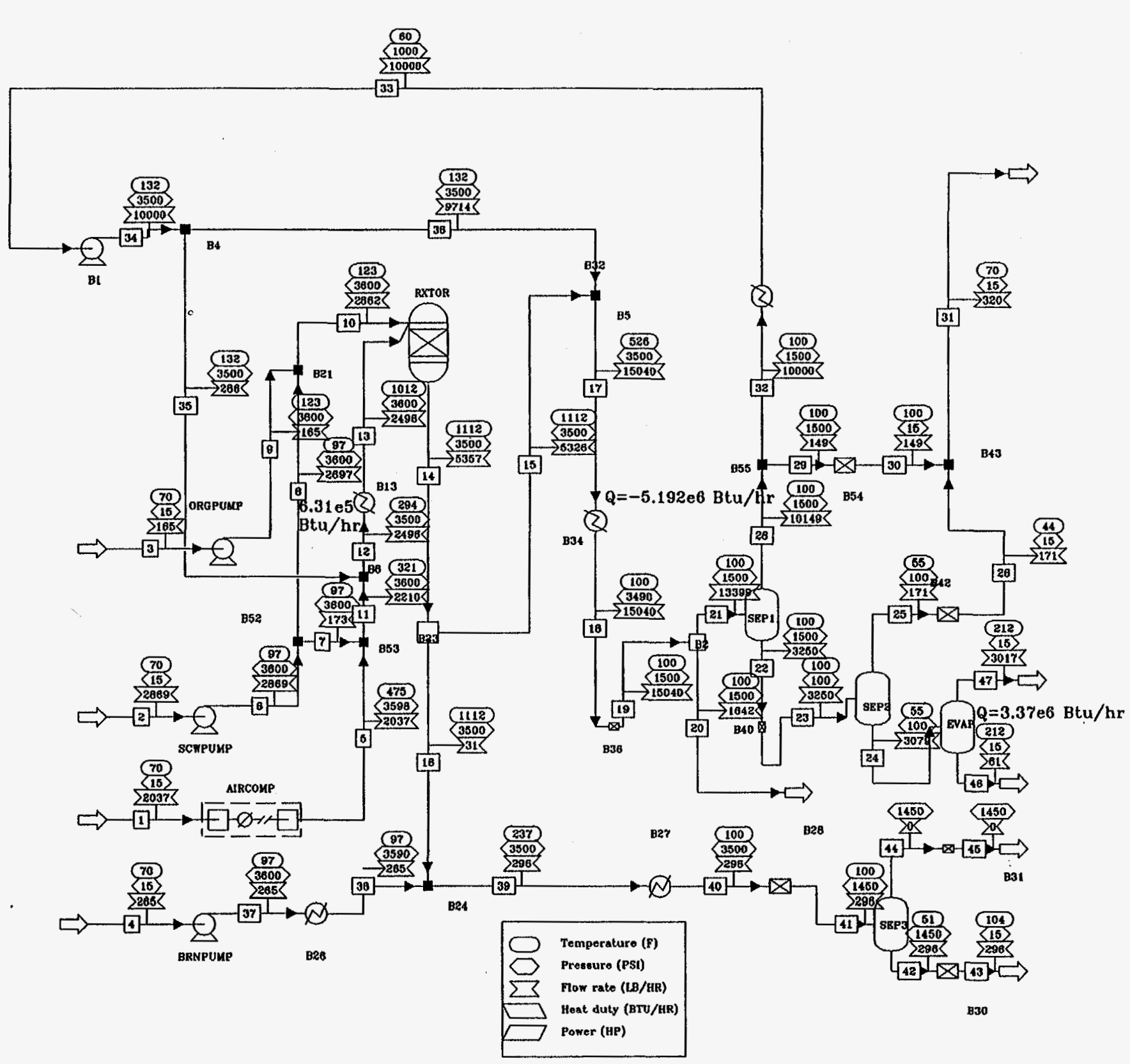




\begin{tabular}{|c|c|c|c|c|c|c|c|c|c|c|c|c|c|}
\hline \multicolumn{14}{|c|}{$80 \% 5 \mathrm{SCW}$ and $20 \% \mathrm{CO}$ in the Core Faed } \\
\hline Stream 10 & & 1 & 2 & 3 & 4 & 5 & 6 & 7 & 8 & 9 & 10 & 11 & 12 \\
\hline From & & & & & & AARCOMP & SCWPUMP & B52 & B52 & ORGPUMP & B21 & 853 & $B 6$ \\
\hline To & & AIRCOMP & SCWPUMP & ORGPUMP & BRNPUMP & B53 & 1852 & 853 & B21 & B21 & AXTOR & B6 & B13 \\
\hline Phaso & & VAPOR & LLOUIO & LIOUID & LIOUID & VAPOR & LIOUID & LIOUID & LIOUIO & LIQUID & LIOUID & MIXED & MIXED \\
\hline \multicolumn{14}{|c|}{ Substroaam: MIXED } \\
\hline Mass Flow & LAMR & & & & & & & & & & & & \\
\hline 02 & & 428.0000 & 0.0 & 0.0 & 0.0 & 428.0000 & 0.0 & 0.0 & 0.0 & 0.0 & 0.0 & 428.0000 & 428.0000 \\
\hline N2 & & 1609.000 & 0.0 & 0.0 & 0.0 & 1609.000 & 0.0 & 0.01 & 0.0 & 0.0 & 0.0 & 1609.000 & 1809.000 \\
\hline IPA & & 0.0 & 0.0 & 165.0000 & 0.0 & 0.0 & 0.0 & 0.0 & 0.0 & 165.0000 & 165.0000 & 0.0 & 0.0 \\
\hline WATER & & 0.0 & 2869.000 & 0.0 & 265.0000 & 0.0 & 2869.000 & 172.5000 & 2696.600 & 0.0 & 2698.500 & 172.5000 & 172.8200 \\
\hline $\mathrm{CO} 2$ & & 0.0 & 0.0 & 0.0 & 0.0 & 0.0 & 0.0 & 0.0 & 0.0 & 0.0 & 0.0 & 0.0 & 285.6800 \\
\hline NACL & & 0.0 & 0.0 & .1000000 & 0.0 & 0.0 & 0.0 & 0.0 & 0.0 & .10000000 & .1000000 & 0.0 & 0.0 \\
\hline \multicolumn{14}{|l|}{ Mass Frac } \\
\hline \begin{tabular}{|l|}
02 \\
\end{tabular} & & .2101129 & 0.0 & 0.0 & 0.0 & 2101129 & 0.0 & 0.0 & 0.0 & 0.0 & 0.0 & .1937090 & .1715007 \\
\hline \begin{tabular}{|l|} 
N2 \\
\end{tabular} & & .7898871 & 0.0 & 0.0 & 0.0 & .7898871 & 0.0 & 0.0 & 0.0 & 0.0 & 0.0 & .7282190 & .6447605 \\
\hline IPA & & 0.0 & 0.0 & .9993943 & 0.0 & 0.0 & 0.0 & 0.0 & 0.0 & .9993943 & .0576600 & 0.0 & 0.0 \\
\hline WATER & & 0.0 & 1.000000 & 0.0 & 1.000000 & 0.0 & 1.000000 & 1.000000 & 1.000000 & 0.0 & .9423050 & .0780719 & .0692526 \\
\hline $\mathrm{CO}_{2}$ & & 0.0 & 0.0 & 0.0 & 0.0 & 0.0 & 0.0 & 0.0 & 0.0 & 0.0 & 0.0 & 0.0 & .1144791 \\
\hline NACL & & 0.0 & 0.0 & $6.05694 E-4$ & 0.0 & 0.0 & 0.0 & 0.0 & 0.0 & $6.05694 \mathrm{E}-4$ & $3.49455 E-5$ & 0.0 & 0.0 \\
\hline Total Flow & LOMOUHR & 70.81213 & 159.2637 & 2.747322 & 14.70973 & 70.81213 & 159.2537 & 9.575205 & 149.6786 & 2.747322 & 152.4258 & 80.38734 & 86.89639 \\
\hline Total Flow & LEHAR & 2037.000 & 2869.000 & 165.1000 & 265.0000 & 2037.000 & 2069.000 & 172.5000 & 2696.500 & 185.1000 & 2861.600 & 2209.500 & 2495.500 \\
\hline Total Flow & CUFTAR & 27365.46 & 46.04469 & 3.212387 & 4.262995 & 215.4203 & 45.75583 & 2.751091 & 43.00474 & 3.342847 & 47.88659 & 186.4809 & 196.7384 \\
\hline Temperature & $F$ & 70.00000 & 70.00000 & 70.00000 & 70.00000 & 474.5000 & 96.64977 & 96.64977 & 96.64977 & 123.3067 & 123.0729 & 321.1481 & 294.4542 \\
\hline Pressure & PSI & 14.70000 & 14.70000 & 14.70000 & 14.70000 & 3598.000 & 3600.000 & 3600.000 & 3600.000 & 3600.000 & 3600.000 & 3600.000 & 3500.000 \\
\hline Vapor Frac & & 1.000000 & 0.0 & 0.0 & 0.0 & 1.000000 & 0.0 & 0.0 & 0.0 & 0.0 & 0.0 & .9249574 & .9224265 \\
\hline Lquald Frac & & 0.0 & 1.000000 & 1.000000 & 1.000000 & 0.0 & 1.000000 & 1.000000 & 1.000000 & 1.000000 & 1.000000 & .0750426 & .0776734 \\
\hline Solld Frac & & 0.0 & 0.0 & 0.0 & 0.0 & 0.0 & 0.0 & 0.0 & 0.0 & 0.0 & 0.0 & 0.0 & 0.0 \\
\hline Enthalpy & BTUR.BMOL & .52 .34120 & $-1.2301 \mathrm{E}+5$ & $-1.2958 \mathrm{E}+5$ & $-1.2301 E+5$ & 2723.120 & $-1.2236 \mathrm{E}+5$ & $-1.2236 E+5$ & $-1,2236 E+5$ & $-1.2695 \mathrm{E}+5$ & $-1.2244 E+5$ & .12176 .78 & .24210 .66 \\
\hline Enthaipy & BTuna & -1.819535 & -8827.949 & -2156.184 & .6827 .949 & 94.66370 & -6791.935 & 6791.935 & -6791.935 & 2112.522 & 6521.956 & -442.9865 & -843.0450 \\
\hline Enthalpy & BTUMA & -3706.392 & $-1.9589 E+7$ & $-3.6599 E+5$ & $-18094 E+6$ & $1.92030 \mathrm{E}+5$ & $-1.8486 E+7$ & $-1.1716 E+6$ & $-1.0314 \mathrm{E}+7$ & $-3.4878 E+5$ & $-1.8663 E+7$ & $-9.7878 E+5$ & $-2.1038 E+6$ \\
\hline Entropy & BTUMBMOL-A & .8647316 & -39.20169 & -106.5672 & -39.20159 & -6.306702 & -38.36061 & -38.36061 & -38.36067 & .109 .3147 & 39.39546 & -9.820050 & .9 .689554 \\
\hline Entropy & BTURE-R & .0300608 & .2 .176019 & -1.773316 & -2.176019 & .2192396 & -2.129338 & -2.129338 & $\begin{array}{l}-2.129338 \\
\end{array}$ & -1.719193 & -2.098436 & -.3572798 &. .3339201 \\
\hline Density & LBMOUCUFT & $2.58765 \mathrm{E}-3$ & 3.458677 & .8552276 & 3.45867 & .3287162 & 3.480512 & 3.480512 & 3.480512 & .8218508 & 3.183059 & .4310523 & .4416849 \\
\hline Density & LB/CUFT & .0744368 & 62.30904 & 54.39481 & 62.30904 & 9.455933 & 62.70240 & 62.70240 & 62.70240 & 49.38903 & 59.76787 & 11.84776 & 12.68436 \\
\hline Averaga MW & & 28.76626 & 18.01528 & 60.09489 & 18.01628 & 28.76628 & $18.0152 \mathrm{~B}$ & 18.01528 & 18.01528 & 60.09489 & 18.77372 & 27.48567 & 28.71811 \\
\hline
\end{tabular}




\begin{tabular}{|c|c|c|c|c|c|c|c|c|c|c|c|c|c|}
\hline \multicolumn{14}{|c|}{$80 \% \mathrm{SCW}$ and $20 \%$ CO2 in the Core Foed } \\
\hline Stream BD & & 13 & 14 & 15 & 16 & 17 & 18 & 19 & 20 & 21 & 122 & 23 & 24 \\
\hline From & & B13 & RXTOR & B23 & 823 & 832 & B34 & 836 & $B 2$ & 62 & SEPP1 & B40 & SEP2 \\
\hline To & & RXTOR & 823 & B32 & 824 & 634 & 1336 & B2 & & SEP1 & $B 40$ & SEP2 & EVAP \\
\hline Phase & & VAPOR & MIXED & MIXED & VAPOR & MIXED & MIXED & MIXED & VAPOR & MIXED & LIOUIO & MIXED & LIQUID \\
\hline \multicolumn{14}{|c|}{ Substraam: MIXED } \\
\hline Mass Flow & LBAHR & & & & & & & & & & & & \\
\hline 02 & & 428.0000 & 32.84869 & 3264689 & 0.0 & 32.64689 & 32.64689 & 32.64689 & 32.84689 & 0.0 & 0.0 & 0.0 & 0.0 \\
\hline N2 & & 1609.000 & 1609.000 & 1609.000 & 0.0 & 1609.000 & 1809.000 & 1609.000 & 1609.000 & 0.0 & 0.0 & 0.0 & 0.0 \\
\hline IPA & & 0.0 & 0.0 & 0.0 & 0.0 & 0.0 & 0.0 & 0.0 & 0.0 & 0.0 & 0.0 & 0.0 & 0.0 \\
\hline WATER & & 172.8200 & 3067.172 & 3036.500 & 30.67172 & 3047.369 & 3047.369 & 3047.369 & 0.0 & 3047.369 & 3036.011 & 3036.011 & 3035.849 \\
\hline $\mathrm{CO} 2$ & & 285.6800 & 648.1813 & 648.1813 & 0.0 & 10351.31 & 10351.31 & 10351.31 & 0.0 & 10351.31 & 213.4715 & 213.4715 & 42.65723 \\
\hline NACL & & 0.0 & .1000000 & .1000000 & 0.0 & .1000000 & .1000000 & .1000000 & 0.0 & .1000000 & .0999999 & .0999999 & .0999999 \\
\hline \multicolumn{14}{|l|}{ Mass Frac } \\
\hline 02 & & .1716087 & $6.09413 E-3$ & $6.12923 E-3$ & 0.0 & $2.17064 E-3$ & $2.17061 \mathrm{E}-3$ & $2.17061 \mathrm{E}-3$ & .0198686 & 0.0 & 0.0 & 0.0 & 0.0 \\
\hline N2 & & .6447605 & .3003491 & .3020786 & 0.0 & 1069783 & .1069783 & .069783 & .9801133 & 0.0 & 0.0 & 0.0 & 0.0 \\
\hline IPA & & 0.0 & 0.0 & 0.0 & 0.0 & 0.0 & 0.0 & 0.0 & 0.0 & 0.0 & 0.0 & 0.0 & 0.0 \\
\hline WATER & & .0692528 & .5725433 & .5700818 & 1.000000 & 2026118 & 2026118 & 2026118 & 0.0 & 22744363 & .9342772 & .9342772 & .9861115 \\
\hline $\mathrm{CO} 2$ & & .1144781 & .1209948 & .1216916 & 0.0 & .6882326 & .6882326 & .6882326 & 0.0 & .725663 & .0656919 & .0656919 & .0138560 \\
\hline NACL & $\therefore$ & 0.0 & $1.86668 E-5$ & $1.87743 E-5$ & 0.0 & 6.64875E-6 & $0.64876 \mathrm{E}-6$ & $6.64876 E-6$ & 0.0 & $7.46337 E-6$ & $3.07732 E \cdot 5$ & $3.07732 E-5$ & $3.24822 E-5$ \\
\hline Total Flow & LBMOLAR & 86.89639 & 243,4406 & 241.7381 & 1.702539 & 462.8180 & 462.8180 & 462.8180 & 58.45689 & 404.3611 & 173.3765 & 173.3765 & 169.4862 \\
\hline Total Flow & LBAR & 2495.500 & 5357.100 & 6328.428 & 30.67172 & 15040.43 & 15040.43 & 15040.43 & 1641.647 & 13398.78 & 3249.582 & 3249.582 & 3078.606 \\
\hline Total Flow & CUFTAR & 406.6212 & 1136.785 & 1129.447 & 7.176998 & $\mathbf{1 1 7 4 . 5 1 7}$ & 335.2434 & 754.6478 & 233.4406 & 310.2972 & 62.36719 & 332,4761 & 48.90594 \\
\hline Temperature & $F$ & 1012.000 & 1112.000 & 1112.000 & 1112.000 & 625.8260 & 100.0000 & 100.0000 & 100.0000 & 100.0000 & 100.0000 & 100.0000 & 54.75034 \\
\hline Pressure & PSI & 3600.000 & 3500.000 & 3500.000 & 3500.000 & 3500.000 & 3490.000 & 1500.000 & 1500.000 & 1500.000 & 1500,000 & 100.0000 & 100.0000 \\
\hline Vapor Frac & & 1.000000 & .9999929 & .9999928 & 1.000000 & 9999961 & .8371153 & .6355882 & 1.000000 & .5843891 & 0.0 & .0281232 & 0.0 \\
\hline Uquild Frac & & 0.0 & $7.09762 E-6$ & $7.14747 E-6$ & 0.0 & $3.86428 E-6$ & 3628047 & .3644118 & 0.0 & .4156109 & 1.000000 & .9718768 & 1.000000 \\
\hline Solid Frac & & 0.0 & 0.0 & 0.0 & 0.0 & 0.0 & 0.0 & 0.0 & 0.0 & 0.0 & 0.0 & 0.0 & 0.0 \\
\hline Enthalpy & BTURВMOL & -16950.47 & .75127 .08 & .74975 .40 & -96856.50 & $-1.2172 E+5$ & $-1.3294 E+5$ & $-1,3200 E+5$ & -96.22086 & $-1.5211 E+5$ & $-1.2390 E+5$ & $-1.2453 \mathrm{E}+5$ & $-1.2350 E+5$ \\
\hline Enthalpy & BTUR_B & -590.2363 & 3413.971 & -3402.732 & .5376 .353 & .3745 .667 & -4090.862 & -4061.700 & -3.426298 & -4590.624 & -6610.262 & -6644.146 & -6799.157 \\
\hline Enthalpy & BTUAAR & $-1.4729 \mathrm{E}+6$ & $-1.8289 E+7$ & $-1.8124 E+7$ & $-1.6490 E+5$ & $-5.6336 \mathrm{E}+7$ & $-6.1528 E+7$ & $8.1090 E+7$ & $\begin{array}{l}-5624.772 \\
\end{array}$ & $-6.1507 \mathrm{E}+7$ & $-2.1481 E+7$ & $-2.1591 E+7$ & $-2.0932 E+7$ \\
\hline Entropy & BTURBMOL-R & -2.533908 & -8.238831 & -8.209482 & -13.21078 & -8.420218 & .22 .81701 & .20 .47440 & -9.142892 & .24 .55066 & -37.66201 & -38.25909 & -39.43336 \\
\hline Entropy & BTULER.R & .0882338 & .3743940 & .3725845 & .7333095 & .2591035 & -.7021158 & .6300299 & -.3255664 & .7409132 & -2.009399 & -2.041255 & -2.170921 \\
\hline Densily & LBMOUCUFT & .2137561 & .2141483 & .2140323 & .2372216 & .3940498 & 1.380543 & .6133713 & .2504143 & 1.303141 & 3.309520 & .5214704 & 3.465554 \\
\hline Density & LB/CUFT & 6.138672 & 4.712500 & 4.715963 & 4.273614 & 12.80563 & 44.86421 & 18.93303 & 7.032395 & 43.18047 & 62.03009 & 9.773882 & 62.94953 \\
\hline Average $\mathrm{MW}$ & & 28.71811 & 22.00578 & 22.03388 & 18.01628 & 32.49750 & 32.49750 & 32.49750 & 28.08304 & 39.13568 & 18.74293 & 18.74293 & 18.16435 \\
\hline
\end{tabular}




\begin{tabular}{|c|c|c|c|c|c|c|c|c|c|c|c|c|}
\hline \multicolumn{13}{|c|}{$80 \%$ SCW and $20 \%$ CO2 in the Core Food } \\
\hline Stream ID & & 25 & 26 & 28 & 29 & 30 & 31 & 32 & 33 & 34 & 35 & 36 \\
\hline From & & SEP2 & B42 & SEP1 & Bas5 & B54 & E43 & B5s & B5 & B1 & Ba & B4 \\
\hline To & & $B 42$ & $B 43$ & B55 & B54 & B43 & & B5 & Bi & $B 4$ & $B 6$ & B32 \\
\hline Phase & & VAPOR & VAPOR & VAPOR & VAPOR & VAPOR & VAPOR & VAPOR & LIQUID & LIQVID & LIRUIO & LLQUid \\
\hline \multicolumn{13}{|c|}{ Substroaan: MIXED } \\
\hline Mass Flow & LВАН & & & & & & & & & & & \\
\hline 02 & & 0.0 & 0.0 & 0.0 & 0.0 & 0.0 & 0.0 & 0.0 & 0.0 & 0.0 & 0.0 & 0.0 \\
\hline N2 & & 0.0 & 0.0 & 0.0 & 0.0 & 0.0 & 0.0 & 0.0 & 0.0 & 0.0 & 0.0 & 0.0 \\
\hline IPA & & 0.0 & 0.0 & 0.0 & 0.0 & 0.0 & 0.0 & 0.0 & 0.0 & 0.0 & 0.0 & 0.0 \\
\hline WATER & & .1622805 & .1622605 & 11.35560 & .1669377 & .1669377 & .3291981 & 11.18867 & 11.18867 & 11.18867 & 3199958 & 10.86667 \\
\hline $\mathrm{CO} 2$ & & 170.8142 & 170.8142 & 10137.85 & 149.0356 & 149.0358 & 319.8498 & 9988.812 & 9988.812 & 9988.812 & 285.6800 & 9703.134 \\
\hline NACL & & 0.0 & 0.0 & 0.0 & 0.0 & 0.0 & 0.0 & 0.0 & 0.0 & 0.0 & 0.0 & 0.0 \\
\hline \multicolumn{13}{|l|}{ Mass Frac } \\
\hline 02 & & 0.0 & 0.0 & 0.0 & 0.0 & 0.0 & 0.0 & 0.0 & 0.0 & 0.0 & 0.0 & 0.0 \\
\hline N2 & & 0.0 & 0.0 & 0.0 & 0.0 & 0.0 & 0.0 & 0.0 & 0.0 & 0.0 & 0.0 & 0.0 \\
\hline IPA & & 0.0 & 0.0 & 0.0 & 0.0 & 0.0 & 0.0 & 0.0 & 0.0 & 0.0 & 0.0 & 0.0 \\
\hline WATER & & $9.49022 E-4$ & 9.49022E-4 & $1.11887 \mathrm{E}-3$ & $1.11887 \mathrm{E}-3$ & $1.11887 E-3$ & $1.02817 \mathrm{E}-3$ & $1.11887 E-3$ & 1.11887E-3 & $1.11887 E-3$ & $1.11887 E-3$ & $1.11887 \mathrm{E}-3$ \\
\hline $\mathrm{CO} 2$ & & .9990510 & .9990510 & .9988812 & .9988812 & .9988812 & .9989718 & .9988612 & .9988812 & .9988812 & .9988912 & .9988812 \\
\hline NACL & & 0.0 & 0.0 & 0.0 & 0.0 & 0.0 & 0.0 & 0.0 & 0.0 & 0.0 & 0.0 & 0.0 \\
\hline Total Flow & LBMOLHA & 3.890284 & 3.890284 & 230.9846 & 3.395684 & 3.395684 & 7.286968 & 227.5890 & 227.5890 & 227.5990 & 6.509044 & 221.0799 \\
\hline Total Flow & LBAR & 170.9765 & 170.9765 & 10149.20 & 149.2025 & 149.2025 & 320.1790 & 10000.00 & 10000.00 & 10000.00 & 288.0000 & 9714.000 \\
\hline Total Flow & CUFTARR & 206.3403 & 1420.610 & 512.0043 & 7.526929 & 1380.599 & 28002.792 & 504.4774 & 194.4409 & 340.2165 & 9.730192 & 330.4863 \\
\hline Temperature & $F$ & 54.75034 & 43.90379 & 100.0000 & 100.0000 & 100.0000 & 70.34032 & 100.0000 & 60.00000 & 131.6183 & 131.6183 & 131.6183 \\
\hline Prossure & PSt & 100.0000 & 14.70000 & 1500.000 & 1500.000 & 14.70000 & 14.70000 & 1500.000 & 1000.000 & 3500.000 & 3500.000 & 3500.000 \\
\hline Vapor Frac & & 1.000000 & 1.000000 & 1.000000 & 1.000000 & 1.000000 & 1.000000 & 1.000000 & 0.0 & 0.0 & 0.0 & 0.0 \\
\hline Lquid Frac & & 0.0 & 0.0 & 0.0 & 0.0 & 0.0 & 0.0 & 0.0 & 1.000000 & 1.000000 & 1.000000 & 1.000000 \\
\hline Solid Frac & & 0.0 & 0.0 & 0.0 & 0.0 & 0.0 & 0.0 & 0.0 & 0.0 & 0.0 & 0.0 & 0.0 \\
\hline Enthalpy & BTURBMOL & $-1.6934 \mathrm{E}+5$ & $-1.6934 E+5$ & $\cdot 1.7098 E+5$ & $-1.7098 E+5$ & $-1,6881 E+5$ & $-1.6909 E+5$ & $-1.7098 \mathrm{E}+5$ & $.17405 E+5$ & $-1.7284 \mathrm{E}+5$ & $-1.7284 E+5$ & $-1.7284 E+5$ \\
\hline Enthalpy & BTURB & -3863.010 & -3853.010 & .3891 .371 & -3891.371 & .3841 .962 & 3847.862 & 3891.371 & 3961.166 & -3933.706 & -3933.706 & -3933.706 \\
\hline Enthatpy & BTUNAR & $-6.5877 \mathrm{E}+5$ & $-6.5877 E+5$ & $-3.9494 \mathrm{E}+7$ & $5.8060 \mathrm{E}+5$ & $-5.7323 E+5$ & $-1.2320 \mathrm{E}+6$ & $3.8914 \mathrm{E}+7$ & -3.9612E+7 & $-3.9337 \mathrm{E}+7$ & $-1.1250 E+6$ & $-3.8212 E+7$ \\
\hline Enlropy & BTUR_BMOL-R & -3.631454 & .1098175 & .10 .69097 & $\begin{array}{l}-10.69097 \\
\end{array}$ & 1.050977 & .5600596 & -10.69097 & -16.18714 & -14.74262 & -14.74262 & -14.74262 \\
\hline Entropy & BTUนB-R & .0826278 & $2.49871 \mathrm{E}-3$ & -2433147 & -.2433147 & .0239180 & .0127628 & .2433147 & .3684014 & -.3355258 & .3355250 & -.3355258 \\
\hline Density & LBMOUCUFT & .0188537 & $2.73865 E-3$ & .4611380 & .4511380 & $2.45957 \mathrm{E}-3$ & 2.59954 E- 3 & .4511380 & 1.170479 & .6689534 & .6689534 & .6689594 \\
\hline Density & LB/CUFT & .8286141 & .1203628 & 19.82249 & 19.82249 & .0080708 & .1142357 & 19.82249 & 51.42951 & 29.39305 & 29.39305 & 29.39305 \\
\hline Average MW & & 43.94962 & 43.94962 & 43.93887 & 43.93887 & 43.99887 & 43.94461 & 43.93887 & 43.93887 & 43.93887 & 43.93887 & 43.99887 \\
\hline
\end{tabular}




\begin{tabular}{|c|c|c|c|c|c|c|c|c|c|c|c|c|}
\hline & & & & & $30 \%$ SCW and $20 \%$ & $\mathrm{CO} 2$ in the Core Fes & & & & & & \\
\hline Stream ID & & 37 & 36 & 39 & 40 & 41 & 42 & 43 & 44 & 45 & 46 & 47 \\
\hline From & & BRAPPUMP & 826 & B24 & 827 & 828 & SEP3 & B30 & SEP 3 & B31 & EVAP & EVAP \\
\hline To & & B28 & 824 & 827 & B28 & SEP3 & 830 & & 831 & & & \\
\hline Phase & & LIQUID & Llouid & LIOUIO & LOQU1D & LLQUID & LLQUID & LLQUID & Missina & MISSING & LIQUid & VAPOR \\
\hline \multicolumn{13}{|c|}{ Substroam: MIXED } \\
\hline Mass Flow & LB/HR & & & & & & & & & & & \\
\hline 02 & & 0.0 & 0.0 & 0.0 & 0.0 & 0.0 & 0.0 & 0.0 & 0.0 & 0.0 & 0.0 & 0.0 \\
\hline $\mathrm{N} 2$ & & 0.0 & 0.0 & 0.0 & 0.0 & 0.0 & 0.0 & 0.0 & 0.0 & 0.0 & 0.0 & 0.0 \\
\hline IPA & & 0.0 & 0.0 & 0.0 & 0.0 & 0.0 & 0.0 & 0.0 & 0.0 & 0.0 & 0.0 & 0.0 \\
\hline WATER & & 265.0000 & 265.0000 & 295.6717 & 295.6717 & 295.6717 & 295.6717 & 295.6717 & 0.0 & 0.0 & 61.03592 & 2974.813 \\
\hline $\mathrm{CO} 2$ & & 0.0 & 0.0 & 0.0 & 0.0 & 0.0 & 0.0 & 0.0 & 0.0 & 0.0 & $1.68014 E-4$ & 42.65706 \\
\hline NACL & & 0.0 & 0.0 & 0.0 & 0.0 & 0.0 & 0.0 & 0.0 & 0.0 & 0.0 & .0999999 & 0.0 \\
\hline \multicolumn{13}{|l|}{ Mass Frao } \\
\hline 02 & & 0.0 & 0.0 & 0.0 & 0.0 & 0.0 & 0.0 & 0.0 & & & 0.0 & 0.0 \\
\hline N2 & & 0.0 & 0.0 & 0.0 & 0.0 & 0.0 & 0.0 & 0.0 & & & 0.0 & 0.0 \\
\hline IPA & & 0.0 & 0.0 & 0.0 & 0.0 & 0.0 & 0.0 & 0.0 & & & 0.0 & 0.0 \\
\hline WATER & & 1.000000 & 1.000000 & 1.000000 & 1.000000 & 1.000000 & 1.000000 & 1.000000 & & & .9983618 & .9858633 \\
\hline $\mathrm{CO} 2$ & & 0.0 & 0.0 & 0.0 & 0.0 & 0.0 & 0.0 & 0.0 & & & $2.74820 E-6$ & .0141367 \\
\hline NACL & & 0.0 & 0.0 & 0.0 & 0.0 & 0.0 & 0.0 & 0.0 & & & $1.63569 \mathrm{E}-3$ & 0.0 \\
\hline Total Flow & LBMOLHR & 14.70973 & 14.70973 & 16.41227 & 16.41227 & 16.41227 & 16.41227 & 18.41227 & 0.0 & 0.0 & 3.389724 & 166.0965 \\
\hline Total Flow & LEAHR & 265.0000 & 265.0000 & 295.6717 & 295.6717 & 295.6717 & 295.6717 & 295.6717 & 0.0 & 0.0 & 61.13609 & 3017.470 \\
\hline Total Flow & CUFTAR & 4.226314 & 4.318507 & 6.245198 & 4.827402 & 4.827402 & 4.702725 & 4.837255 & 0.0 & 0.0 & 1.064425 & 80501.02 \\
\hline Temperature & $F$ & 96.64977 & 96.60000 & 237.1190 & 100.0000 & 100.0000 & 51.40759 & 108.6749 & & & 212.0000 & 212.0000 \\
\hline Prossure & PSI & 3600.000 & 3590.000 & 3500.000 & 3500.000 & 1450.000 & 1450.000 & 14.70000 & 1450.000 & 1450.000 & 14.76595 & 14.76595 \\
\hline Vapor Frac & & 0.0 & 0.0 & 0.0 & 0.0 & 0.0 & 0.0 & 0.0 & & & 0.0 & 1.000000 \\
\hline Lquutd Frac & & 1.000000 & 1.000000 & 1.000000 & 1.000000 & 1.000000 & 1.000000 & 1.000000 & & & 1.000000 & 0.0 \\
\hline Solid Frac & & 0.0 & 0.0 & 0.0 & 0.0 & 0.0 & 0.0 & 0.0 & & & 0.0 & 0.0 \\
\hline Enthalpy & BTUn.EMFOL & $-1.2236 \mathrm{E}+5$ & $-1.2314 \varepsilon+5$ & $-1.2042 E+5$ & $-1.2308 \mathrm{E}+5$ & $-1.2319 \mathrm{E}+5$ & $-1.2319 E+5$ & $-1.2319 E+5$ & & & $-1.2045 E+5$ & $-1.0328 E+5$ \\
\hline Enthalpy & BTURB & -8791.835 & -6835.548 & .6684 .176 & 6832.148 & .6837 .843 & 6837.843 & 6837.843 & & & -6878.570 & .5684 .868 \\
\hline Enthalpy & BTUAR & $-1.7999 E+6$ & $-1.8114 E+6$ & $-1.9763 E+6$ & $-2.0201 E+6$ & $-2.0218 E+8$ & $-2.0218 E+6$ & $-2.0218 E+6$ & & & $-4.0030 E+5$ & $-1.7154 E+7$ \\
\hline Entropy & BTURBMOL-R & -36.36061 & -39.48794 & .35 .10914 & 39.36805 & .39 .31999 & 39.68880 & -39.15815 & & & .34 .89125 & 8.677848 \\
\hline Entropy & BTULA.R & -2.129338 & -2.191914 & -1.948853 & -2.185259 & -2.182591 & -2.203063 & -2.173608 & & & -1.934564 &. .4776717 \\
\hline Densily & LBMOUCUFT & 3.460512 & 3.406209 & 3.129009 & 3.399816 & 3.399816 & 3.489949 & 3,392890 & & & 3.184557 & $2.06328 \mathrm{E}-3$ \\
\hline Density & LB/CUFT & 62.70240 & 61.36380 & 56.36998 & 61.24863 & 61.24863 & 62.87242 & 61.12386 & & & 57.43577 & .0374836 \\
\hline Average $\mathrm{MW}$ & & 18.01628 & 18.01628 & 18.01528 & 18.01528 & 18.01528 & 18.01528 & 18.01528 & & & 18.03572 & 18.16697 \\
\hline
\end{tabular}




\section{ECONOMIC EVALUATION}

An economic evaluation was performed between the Baseline and Case-A. Tables 3 and 4 show the comparison, in terms of the unit equipment cost.

Table 3. Equipment cost for the baseline.

\begin{tabular}{|c|c|c|}
\hline Units & Low Value & High Value \\
\hline Air compressor (500SCFM) & $\$ 30,000$ & $\$ 50,000$ \\
\hline SCW pump (8 gpm) & $\$ 70,000$ & $\$ 100,000$ \\
\hline Organic pump ( $0.5 \mathrm{gpm})$ & $\$ 35,000$ & $\$ 50,000$ \\
\hline Quench pump $(1.59 \mathrm{cfm})$ & $\$ 20,000$ & $\$ 30,000$ \\
\hline Heater for air/water $(1000 \mathrm{~kW})$ & $\$ 30,000$ & $\$ 50,000$ \\
\hline Reactor vessel with two liners & $\$ 200,000$ & $\$ 300,000$ \\
\hline Brine pump $\left(4.25 \mathrm{ft}^{3} / \mathrm{hr}\right)$ & $\$ 50,000$ & $\$ 70,000$ \\
\hline \multicolumn{3}{|l|}{ Brine Heater } \\
\hline Quench piping & $\$ 3,500$ & $\$ 5,000$ \\
\hline Feed Heater/Effuent cooler & $\$ 2,000$ & $\$ 4,000$ \\
\hline Cooldown exchanger & $\$ 1,000$ & $\$ 1,000$ \\
\hline Letdown valve 1 ( $2500 \mathrm{psia})$ & $\$ 5,000$ & $\$ 6,000$ \\
\hline 1st separator (2'OD x 3') & $\$ 150,000$ & $\$ 200,000$ \\
\hline Letdown valve 2 (1500 psia) & $\$ 2,000$ & $\$ 3,000$ \\
\hline 2nd separator (1.5'OD x 2') & $\$ 80,000$ & $\$ 100,000$ \\
\hline Offgas collection & $\$ 2,000$ & $\$ 3,000$ \\
\hline Offgas filters & $\$ 2,000$ & $\$ 3,000$ \\
\hline Evaporator $(9.87 \mathrm{e} 6 \mathrm{Btu} / \mathrm{hr})$ & $\$ 20,000$ & $\$ 200,000$ \\
\hline Brine cooldown & $\$ 2,000$ & $\$ 3,000$ \\
\hline Brine letdown valve & $\$ 40,000$ & $\$ 50,000$ \\
\hline Brine separator & $\$ 40,000$ & $\$ 50,000$ \\
\hline Total & $\$ 746,500$ & $\$ 1,231,000$ \\
\hline
\end{tabular}


Table 4. Equipment cost for Case-A

\begin{tabular}{|c|c|c|}
\hline Units & Low value & High value \\
\hline Air compressor (500 SCFM) & $\$ 30,000$ & $\$ 50,000$ \\
\hline SCW pump (1cfm) & $\$ 70,000$ & $\$ 100,000$ \\
\hline Organic pump (0.5 gpm) & $\$ 35,000$ & $\$ 50,000$ \\
\hline $\mathrm{CO}_{2}$ pump (6cfm) & $\$ 20,000$ & $\$ 30,000$ \\
\hline Heater for water/air $(189 \mathrm{~kW})$ & $\$ 20,000$ & $\$ 30,000$ \\
\hline Reactor vessel with two liners & $\$ 200,000$ & $\$ 300,000$ \\
\hline Brine pump $\left(4.25 \mathrm{ft}^{3} / \mathrm{hr}\right)$ & $\$ 50,000$ & $\$ 70.000$ \\
\hline \multicolumn{3}{|l|}{ Brine Heater } \\
\hline Quench piping & $\$ 3,500$ & $\$ 5,000$ \\
\hline Feed exchanger/effluent cooler & $\$ 2,000$ & $\$ 4,000$ \\
\hline Cooldown exchanger & $\$ 5,000$ & $\$ 7,000$ \\
\hline Letdown valve 1 ( $2500 \mathrm{psia}$ ) & $\$ 5,000$ & $\$ 6,000$ \\
\hline $\mathrm{CO}_{2}$ separator (1st separator) & $\$ 150,000$ & $\$ 200,000$ \\
\hline Letdown valve 2 (1500 psia) & $\$ 2,000$ & $\$ 3,000$ \\
\hline 2nd separator & $\$ 80,000$ & $\$ 100,000$ \\
\hline Letdown valve 3 ( $100 \mathrm{psia})$ & $\$ 500.00$ & $\$ 1,000$ \\
\hline 3rd separator & $\$ 1,000$ & $\$ 2,000$ \\
\hline $\mathrm{CO}_{2}$ condenser $(286 \mathrm{e} 3 \mathrm{Btu} / \mathrm{hr})$ & $\$ 5,000$ & $\$ 10,000$ \\
\hline $\mathrm{O}_{2}$ offgas collection & $\$ 2,000$ & $\$ 3,000$ \\
\hline Offgas filters & $\$ 2,000$ & $\$ 3,000$ \\
\hline Evaporator (3.06e6 Btu/hr) & $\$ 20,000$ & $\$ 200,000$ \\
\hline Brine cooldown & $\$ 2,000$ & $\$ 3,000$ \\
\hline Brine letdown valve & $\$ 2,000$ & $\$ 3,000$ \\
\hline Total & $\$ 757,000$ & $\$ 1,250,000$ \\
\hline
\end{tabular}


The equipment for Case-A is only slightly higher than for the baseline unit. Since the CaseA replaces the water used in the quench stream, it saves a significant amount of energy in the end process unit. The flow sheet simulation indicates that the heat duty of the evaporator for the CaseA is $3.06 \mathrm{e} 6 \mathrm{Btu} / \mathrm{hr}$ vs. $9.87 \mathrm{e} 6 \mathrm{Btu} / \mathrm{hr}$ for the baseline.

This is a difference of about $2000 \mathrm{~kW}$ for the pilot scale unit. This is a significant energy savings resulting from the replacement of water by $\mathrm{CO}_{2}$ for the quenching process. 


\section{CONCLUSIONS}

Supercritical water oxidation (SCWO) shows promise as an economical, environmentallysound technology for effective decontamination of DOE, diverse industrial, military, and municipal wastes. Several process designs are under development to commercialize the technology, and at least one commercial facility of Eco Waste Technologies, Inc. is presently destroying longchain alcohols, glycols, and amines in aqueous wastes from chemical plants in Austin, Texas.

SCWO technology can qualify as a totally enclosed treatment facility. That is, the treated effluent can be held in reserve and analyzed prior to release to the environment. If the effluent does not meet the specifications of the relevant regulations it can be recycled to the reactor and treated again. This feature guarantees that no uncontrolled emissions of environmentally damaging compounds will occur during SCWO treatment. Note that this feature stands in contrast with incineration where the effluent is emitted continuously.

A mixed waste treatment system will have effiuent requirements determined primarily by environmental regulations and policies. The capability of a process to be known as a "closed system", having a very low release to the environment, no liquid waste and a minimal volume of solid waste will be an important factor in selecting treatment technologies and use in mixed waste treatment. The concept of zero discharge, controllable emissions and acceptance by the public is also very important along with costs and schedule of a mixed waste treatment system that ultimately is built and operated.

In order to make the SCWO technology more viable compared to other technologies, this study focused on energy efficiency to use $\mathrm{CO}_{2}$ as a replacement of water in the quench stream and also in a feed stream. $\mathrm{CO}_{2}$ is one of the reaction products and is recycled in the SCWO process. In this study, $\mathrm{NaCl}$ was simulated as an impurity in the end unit process, that is an evaporator. The result indicates that case -1 , replacement of water by $\mathrm{CO}_{2}$, reduces the energy duty of evaporator by $6.81 \mathrm{e} 6 \mathrm{Btu} / \mathrm{hr}$ based on $5330 \mathrm{lb} / \mathrm{hr}$ reaction effluent rate from the reactor.

In addition, the replacement of water in the reactor feed by carbon dioxide would alleviate much of the sticky salt deposit problem because the salts remain in a solid form in the carbon dioxide environment as compared to the water environment due to the lower solubility of salt in carbon dioxide. Also, the higher viscosity of carbon dioxide at the supercritical conditions would minimize the corrosion problem because of the lower mass transfer rate of hetroatoms (e.g.,chlorine, sulphur, etc.) to the wall. If we can prove this phenomena by experiments, it will make SCWO even more advantageous compared to other processes. Due to funding limitations, these comparison could not be included in this study. Because of the many advantages offered by the SCWO relative to other technologies, its development should be continued because research is needed to bridge the gap between the pilot scale and commercialization scale in effectively treating all wastes including the DOE mixed wastes.

Acknowledgment: The equipment cost shown in Tables 3 and 4 was provided by Karen Garcia. I appreciate her effort for that. 


\section{REFERENCES}

1. C.H. Oh, R.J. Kochan, and T.R. Charlton, "Thermal-Hydraulic Modelling of Supercritical Water Oxidation of Ethanol," Energy \& Fuels, Vol.10, No.2, pp.326-332, 1996.

2. C.H. Oh, R.J. Kochan, and T.R. Charlton, "Modelling of Thermal Characteristics in Supercritical Water Oxidation Reactors," Proceedings of ASME Heat Transfer, HTD-Vol.317-2, pp.311-320, 1995

3. R.J. Kochan and C.H. Oh, Preliminary Analytical Modeling Requirements for Thermal Hydraulic Analysis of SCWO Pilot Plant, EG\&G Idaho, Inc., EGG-WTD-10985, November 1993.

4. R.J. Kochan and C.H. Oh, "Preliminary CFD Computer Code Comparison for ThermalHydraulic Analysis of SCWO Reactor," INEL TDF \#ID121217/1020, May 26, 1994.

5. R.J. Kochan and C.H. Oh, CFD Code Selection and Preliminary Validation for ThermalHydraulic Analysis of SCWO Benchscale Reactor, Idaho National Engineering Laboratory, INEL-94/0224, December 1994.

6. R.J. Kochan and C.H. Oh, CFD Model Development and Data Comparison for ThermalHydraulic Analysis of HTO Pilot Scale Reactor, Idaho National Engineering Laboratory, INEL-95/0445, September 1995.

7. FLUENT User's Guide Version 4.3 and FLUENT Code Release of Version 4.3.1, January 1995.

8. D.M.Himmelblau, Basic Principles and Calculations in Chemical Engineering, 5th Edition, Prentice Hall, New Jersey, 1989.

9. ASPEN Technology, Inc., ASPEN PLUS Release 9 Manual, 1994.

10. L. Haar et. al., NBS/NRC Steam Tables, Hemisphere Publishing Corporation, New York, 1984. 